\title{
Finances and National Economy: Frugal Economy as a Forced Approach of the COVID Pandemic
}

\author{
Otilia Manta ${ }^{1,2, *(D)}$, Eglantina Hysa ${ }^{3}(\mathbb{D})$ and Alba Kruja ${ }^{4}(\mathbb{D}$ \\ 1 Financial and Monetary Research Center "Victor Slavescu", Romanian Academy, 050711 Bucharest, Romania \\ 2 Department of Research, Romanian-American University, 012101 Bucharest, Romania \\ 3 Department of Economics, Epoka University, 1032 Tirana, Albania; ehysa@epoka.edu.al \\ 4 Department of Business Administration, Epoka University, 1032 Tirana, Albania; akruja@epoka.edu.al \\ * Correspondence: otilia.manta@icfm.ro
}

check for updates

Citation: Manta, O.; Hysa, E.; Kruja, A. Finances and National Economy: Frugal Economy as a Forced Approach of the COVID Pandemic. Sustainability 2021, 13, 6470. https://doi.org/10.3390/ su13116470

Academic Editor: Donato Morea

Received: 1 May 2021

Accepted: 4 June 2021

Published: 7 June 2021

Publisher's Note: MDPI stays neutral with regard to jurisdictional claims in published maps and institutional affiliations.

Copyright: (c) 2021 by the authors. Licensee MDPI, Basel, Switzerland. This article is an open access article distributed under the terms and conditions of the Creative Commons Attribution (CC BY) license (https:// creativecommons.org/licenses/by/ $4.0 /)$.

\begin{abstract}
This paper aims to create an image both in terms of description and in terms of graphical representation, with multiannual coverage (2007-2019), the evolution of the financial indicators of the population, and their impact on the national economy. The main objective is to establish the basic pillars of the concentrated table of population financial indicators in terms of the values of absolute primary indicators, on the basis of which the values of the three relevant relative indicators that characterize the financial situation of the population were calculated directly for the potential and performance of the national economy, especially in the current context of the COVID-19 pandemic. The research methodology was based on a series of numerical data from public databases, tools, and appropriate research methods based on the calculation of primary indicators, and indicators derived by appropriate calculation formulas, for the identification of factors influencing the financial status of the population at and a comparative analysis of the financial assets and liabilities of households in Romania and the European Union. The results of the paper are given by the evolution of primary indicators on the characterization of the financial situation of the population in 2007-2019, especially for the active population, and are directly influenced by the quality of eligible employment and employed adults, as well as the sustainability of the national economy. The personal contribution of the research team consists of the mathematical correlations given by the population finances for the economy of a state, which are extremely relevant, especially since, depending on their positive or negative levels, systemic financial and social imbalances are created with direct impact on the sustainability of the national economy. Thus, we want to determine these financial indicators relevant to the economy. Additionally, due to the COVID-19 pandemic, the related issues to the population finances have aggravated and as such, there is a need for structural changes and adoptions. Finally, as an immediate and less costly solution, this study comes up with the suggestion of shifting the national economy toward frugality, therefore, significantly supporting sustainable development.
\end{abstract}

Keywords: financial indicators; sustainability; national economy; frugal economy

\section{Introduction}

A frugal economy strives to create more economic, social, and ecological value simultaneously while wisely optimizing the use of all available resources [1,2]. Although the above-mentioned definition is compact and clear, the term frugal depends upon perspectives and has been given too many definitions [3]. Generally, two opposing approaches to frugality are the positive one and the negative one. Frugal innovations in the economy are generally understood to be low-cost and efficacious, new or adapted products (or services), mostly emerging from contexts of institutional voids and resource constraints, involving the creative use of existing resources [4]. Due to COVID-19, resource scarcity is becoming an increasingly pressing issue $[5,6]$. Many businesses and economies are looking to find ways to "do more with less" [7], by trying to maximize the value of the existing 
resources [8]. This is the positive side of the frugal economy. However, the COVID-19 pandemic served as an immediate push to frugality, noted to be a rise of a new experience economy $[9,10]$. On the other side, we see that the COVID-19 pandemic is having a serious negative influence on finances on both, micro and macro levels. At the micro-level, we realize that people that have directly been affected by COVID-19 or lost their income or jobs are trying to find ways to spend less money, pushing them to a forced frugality approach. Businesses are also experiencing the frugality approach, especially those business models that rely on access to credit. They are trying to survive on less, as the individuals are. As a consequence, an amplified impact is prevailing on the overall level of employability and the national economy.

The aim of the paper is to create an image representing both descriptively and graphically the evolution of the financial indicators of the population in the period 2007-2019 by calculating the financial indicators of the population in the previous periods according to the series of numerical data identified in reports and studies that are found mentioned in the papers.

The main objective is to establish the basic pillars of the concentrated table of population financial indicators in terms of the values of absolute primary indicators, based on which relevant relative indicators were calculated that characterize the financial status of the population and directly influence the potential and performance national economy.

The consistency of the set of indicators was built on the basis of data from the National Institute of Statistics, the Ministry of Public Finance, and the National Bank of Romania, considering both the definition of the primary database and the calculation of the dynamic series of proposed indicators. The harmonization of data at the level of 2019 was given by the fact that for 2020, the available data necessary for the calculation of the derived indicators stop at quarters II and III respectively (for a large part of the primary indicators). Therefore, the evolution of the financial status of the population was achieved by building and calculating a group of indicators, for the period 2007-2019.

In the paper, we considered the following hypotheses: calculation of primary indicators, based on which derived indicators were developed, identification of factors influencing the financial status of the population at the national and European level, and a comparative analysis of financial assets and liabilities of households in Romania and the European Union.

Expenditure reductions played a key role in many small open economies during fiscal consolidation, with large declines in public investment [11]. Furthermore, in financial terms, we can say that a frugal economy meets one of two criteria. A frugal economy means an absolute lack of debt, or alternatively, it is debt that returns higher future benefits comparing with the costs of the debt.

In furtherance of the latest development of the COVID-19 pandemic, this work is carried out, in parallel, the permanent development of its own database. The main aim is to create long series of data, as a basis for dynamic analysis, and for further development of new applications, and to see if there are some obvious tracks of the frugality approach in the overall economy of Romania. The consistency of the set of indicators was built on the basis of data from the National Institute of Statistics, the Ministry of Public Finance, and the National Bank of Romania, regarding both the definition of the primary database and the calculation of a dynamic series of proposed indicators. Moreover, the harmonization of data in 2019 was also given by the fact that some of the primary indicators are reported in 2020, but some of these primary indicators are missing compared to 2019. The evolution of the financial situation of the population was summarized by building and calculating a set of 16 indicators. These indicators were proposed by the Center for Financial and Monetary Research (CFMR) [12] and are based on the main data sources at the macroeconomic level (annual reports of the National Bank of Romania and the National Institute of Statistics, as well as data from the National Accounts). Based on these status indicators, a series of useful information was presented that can be correlated with macroeconomic 
statistics, national accounting, financial accounting, and banking statistics, for the period 2007-2019 [13,14].

The novelty of the paper is given by the fact that the analyses so far of the financial indicators relevant to the household sector allowed the drawing of some general conclusions regarding the characteristics highlighted by the population, from a financial point of view, in the analyzed period, but did not highlight the population, (including through comparative analyzes at the level of EU states), as well as to the needs of the development of the saving-investment cycle, primordial to the beneficial evolution of the economy. In this sense, we can consider from our research that the assertion of the population as the priority internal financier of the economy, often unique, which highlights the shortage of investment opportunities specific to households in an economy with financial resources rather unviable, to be authentic. This aspect is also the core of our research based on financial indicators related to the population.

Therefore, through this paper we aim to provide answers to the following research questions:

RQ1: How has the evolution of income, interest rates and dividends, and the development of the banking system in the financial savings of the population progressed?

RQ2: If the frugal economy can serve as a solution to the frequent volatility of finances, and moreover, to the unusual circumstances of the COVID-19 pandemic.

Through this research, we come up with and propose six indicators: (1) rate of financial savings of the population; (2) population savings coefficient; (3) coefficient of indebtedness of the population; (4) population income financing rate; (5) coefficient of financial financing capacity of the population; and (6) population financial employment rate. These financial indicators relevant to the households' sector allow us to put forward conclusions relating to a financial perspective of the population characteristics.

The remainder of this paper is structured as follows. Section 2 describes the relevant literature. This is followed by Section 3, which explores the applied method to calculate each variable and describes the related results. Section 4 presents a further discussion and the results. Finally, the conclusions are discussed in Section 5.

\section{Literature Review}

Many studies are looking to different components that help with the national economy improvement [11,15-32]. For instance, investment in the health sector for EU countries prevails with positive effects on the national economy, especially for employment and household income [15]. Another study for OECD countries emphasizes the roles of demographic structure and intergenerational public transfers and comes up with the conclusion that migration is beneficial to host economies characterized by aging populations and large public sectors [16].

Developing countries should explore different fiscal policies to ensure correct and sustainable public finance in the medium and long term [17]. Research conducted in India, Brazil, and Romania, revealed that bank credit, inflation, and non-performing loans, negatively affected the countries' sustainable economic growth [18]. On the other side, the study conducted by [11], proposes the implementation of budget-neutral investment spending to give rise to long-term welfare meanwhile restraining adverse effects for the public finances. Furthermore, in order to achieve sustained economic growth, a study related to 10 Central and Eastern European and Baltic nations, proposes an efficient transition from a brown economy towards a green economy [19].

For the issue of primary indicators of the population, and directly, of the reference indicator, the wealth of the population has been, is, and will remain a hotly debated topic at the level of national, European, and global economic policies. It is true that population indicators are influenced by numerous internal and external factors, and the work of [20-22] shows that the problem of international migration is not only an economic issue, but also a social, cultural, and politically, with multiple implications not only for the country of origin but also on the host country. The costs that this phenomenon implies affect both the 
countries of origin and the beneficiary country. Moreover, foreign money transfers due to temporary jobs abroad, have an impact on population indicators and are detailed in [23] with the role of remittances as an important source of foreign transfers to countries under development, they are considered a financial development mechanism and can be used for consumption or for investment. Ref. [24] presents the importance of using econometric models to identify the relationship between macroeconomic variables. Ref. [25] studies the role of geographical economics, institutional social science, and endogenous growth theory, in order to provide a new perspective on cohesion policy. Ref. [26] examines the different approaches to measuring individual well-being and social well-being, which have been considered for building alternatives to GDP. Ref. [27] looks at the focus on SMEs, and in particular on their rapid growth, in terms of the Europe 2020 policy strategy. Ref. [28] conducts a study in 169 countries and shows that higher degrees of political instability are associated with lower GDP growth rates per capita. Another study analyzes and interprets the data for the entire interval from 1990 to the present regarding the economic and social situation of Romania [29]. Similarly, a study analyzes the level of the European Union and in each country, the correlation between the Gross Domestic Product per capita, imports, exports, and the degree of coverage of imports by exports, while achieving the ranking of Member States mentioned indicators [30].

The paper [31] presents mechanisms and models for supporting the poor population, especially in the context of European support in the 2021-2027 programming period. Ref. [32] analyzes the economic considerations on which to base the economic growth forecast, presenting considerations on the theory of economic growth, the system of indicators used, economic growth modeling, or the trend based on which economic growth can be analyzed.

\section{Research Methodology}

In the paper, we considered the following aspects: calculation of primary indicators, based on which the 16 derived indicators were developed, identification of factors influencing the financial situation of the population at the national and European level, as well as a comparative analysis of assets and liabilities of households in Romania and the European Union.

Regarding the primary indicators, they registered mainly higher values compared to the previous period. In 2019, there are also indicators with lower values, namely Bank deposits of the population, Financial saving, Gross formation of fixed capital of the population, Interest rate collected by the population on savings instruments, Financial investments of the population, Population; as for the year 2020, from the data available so far, the Gross Domestic Product, the interest rates collected and paid show decreasing values compared to the previous year.

The primary data identified were based on the databases of the National Bank of Romania (from the National Financial Accounts 2007-2019 and the monthly bulletins from 2007 to 2021) and the National Institute of Statistics (Statistical Yearbook of Romania, editions 2007-2019, Statistical Bulletins monthly from 2007 to 2021).

As for the derived indicators, in 2019, compared to 2018, most of them recorded slightly lower values (10). For 2020, as most of the reported data are only available up to the level of the third quarter, we calculated only four indicators that registered values higher than 2019.

Regarding the factors influencing the financial situation of the population, the evolution of economic growth (GDP at the national level), the evolution of the active population in the economy and the labor market, the evolution of the sustainability of public finances, as well as the evolution of demographic changes at the national level were taken into account.

In the analysis of the financial wealth of households in Romania and the European Union, we took into account the comparative situation of financial assets and liabilities (commitments) of households as a whole, the types of financial instruments, as well as a brief analysis of assets worldwide. In 2019, the assets of households in the EU-27 increased 
compared to debt, which decreased, and in terms of global wealth, they had an upward trend, although they are unevenly distributed.

For the construction of the relevant indicators selected for the purpose of assessing the financial situation of the population, for the period 2007-2019, the following absolute indicators were used:

$\mathrm{AFE}=$ Total financial assets, receivables, of the residential sectors, including, cash, deposits, loans, securities, etc.

$\mathrm{AFP}=$ Gross financial assets: financial assets held by the population at a given time, regardless of nature, maturity, degree of risk, and forms of holding. It is also called the financial wealth of the population, is both a flow and a stock indicator, representing the receivables of the population in the form of bank investments, IPB or financial investments, IPF, that is, cash, demand deposits, term deposits, short-term securities, long-term securities, loans, and others.

LAC = Liquid financial assets: cash (from income) + transferable deposits + securities with a term of less than 3 months, held by the population, in order to be able to repay the loans committed at maturity.

$\mathrm{CHB}=$ Total monetary expenditure of the population: expresses the expenditures related to the consumption of goods and services, for investments, taxes, and financial expenses, including interest.

$\mathrm{CHD}=$ Interest expenditure: expresses the monetary expenditure made annually by the population for the payment of interest.

$\mathrm{NPP}=$ Net financing capacity of the economy, all resident sectors, positive or negative (financing required): represents the net financing capacity of the economy, as the difference between all financial assets, financial receivables of resident sectors, and all their financial debts, the difference can be, as a rule, positive, but sometimes also negative, signifying a need to finance the economy.

$\mathrm{CNP}=$ Net financing capacity of the population, positive or negative (financing required): represents the net financing capacity of the population, as the difference between the financial assets, the financial receivables of the population, and its financial debts, the difference can be, as a rule, positive, but sometimes also negative, signifying a need for financing the population.

$\mathrm{CRP}=$ Bank loans received by the population: the total bank loans received by the population, but also loans on other banking instruments, regardless of maturity and risks.

CTP $=$ Total financial receivables of the population: financial saving, total financial receivables of the population, regardless of nature, instrument, and institution.

DEP = Bank deposits of the population: the total of bank deposits and other bank savings instruments of the population, regardless of maturity, risks or income generated.

DTP = Financial debts of the population: total financial debts of the population, regardless of nature (banking or non-banking), instrument and institution, recorded at the end of the year.

ECF = Financial savings: the total savings, through financial instruments of any kind, held by the population at the end of the year, in the form of their banking and financial assets, constituting the total financial receivables of the population (CTP).

$\mathrm{FBP}=$ Gross fixed capital formation of the population: represents the value of durable goods intended for purposes other than consumer, utilitarian, with a certain value, acquired by the population, usually through investments, to be used for a period longer than a year.

IFV = Financial investments of the population, banking, and non-banking: the monetary value of the financial investments of the population, banking and non-banking, made over a period of one year, meaning the acquisition of banking and financial saving instruments.

$\mathrm{IPF}=$ Investments in the financial market, in various financial securities, of the population, in shares and participations (ACP), and in debt securities, such as bonds (TLO). 
IVF = Total physical investments of the population (IVT-IFV): the monetary value of the total physical investments of the population, made during a period of one year, meaning payments for the acquisition of durable goods, with a lifespan over one year.

IVT = Total investments of the population: total investments of the population, made during a period of one year (IVF + IFV).

PFE = Total financial liabilities, commitments, debts of the institutional sectors of the economy, according to SNA. On the whole, the difference between the receivables and financial debts of the sectors generating a negative or positive balance, the negative balance representing a need for external financing.

PFP = Financial liabilities of the population, commitments, at a given time, regardless of nature, maturity, degree of risk and forms of holding; it is also called the financial debt of the population; it is both an indicator of flow and stock, representing commitments, debts of the population in the form of liquid debts, in the short, medium, and long term, banking and non-banking.

GDP = Gross domestic product: the main macroeconomic aggregate of the national accounting system that expresses the gross value added of goods and services reached in the last stage of the economic circuit, which were produced within a country by domestic and foreign economic agents in a certain period time, usually a year.

POP = Population: a group of individuals gathered by citizenship ties and by establishing domicile on the territory of the state, in relation to which the latter exercises its sovereign power the entire set of data from which a sample is selected and in connection with which the auditor wishes to formulate its conclusions, statistically being evaluated at the end of the year, according to the data from the Statistical Yearbook.

Rdi = Interest rate collected (on deposits), which expresses the interest rate collected by the population on savings instruments, such as bank deposits, purchased financial securities, etc.

$\operatorname{Rdp}=$ Interest rate paid (on loans), which expresses the interest rate paid by the population on committed loans, such as bank loans.

GNP = Cash income of the population: the total cash income obtained by the population, for periods of one year, from any available source, such as cash income, but also other liquidity available during the year.

$\mathrm{VDB}=$ Gross disposable income of the population: the balance of the income account and measures the part of the created value that the population has for final consumption and gross economy (from which it achieves financial savings).

The relevant indicator sheets are presented below.

Indicator 1 (calculation procedure)

1. Section: I. Financial macroeconomics;

2. Chapter: 4. Assessing the financial condition of the population;

3. Paragraph: 4.3. Evaluation of the saving structure;

4. Name: The rate of financial saving of the population;

5. Symbol: Ref;

6. Degree of synthesis: derived indicator;

7. Data source: Financial Accounts-NBR and Statistical Yearbook;

8. Calculation formula:

$$
\operatorname{Ref}=\frac{\mathrm{ECF}}{\mathrm{GDP}} \times 100
$$

9. Explanations of the previous notation:

- $\quad \mathrm{ECF}=$ total savings, through financial instruments of any kind, held by the population at the end of the year, in the form of their banking and financial assets, constituting the total financial receivables of the population (CTP).

- $\mathrm{GDP}=$ Gross domestic product: the main macroeconomic aggregate of the national accounting system that expresses the gross value added of goods and services reached in the last stage of the economic circuit, which were produced within a country by domestic and foreign economic agents in a certain period of time, usually one year. 
10. Economic significance: it is an indicator of stock; the indicator highlights the financial saving per inhabitant, the saving potential of the population; the indicator can be determined by stock or flow (savings made during the year).

11. Utility in economic analysis: allows the analysis on the whole, but also on types of savings (through indicators derived from detail) of the saving potential of the population and comparative analysis in time or space.

12. How to use in the paper: the indicator can be correlated with other generic indicators of financial saving of the population, but also with indicators specific to the financial status of the population. At the same time, the indicator can be integrated into the network of indicators for evaluating the financial status of the population, which highlights their interconnections and co-determinations in the perspective of a complex synthetic evaluation indicator.

Indicator 2 (calculation procedure)

1. Section: I. Financial macroeconomics;

2. Chapter: 4. Assessing the financial condition of the population;

3. Paragraph: 4.3. Evaluation of the saving structure;

4. Name: Coefficient of inclination to save the population;

5. Symbol: Cie;

6. Degree of synthesis: derived indicator;

7. Data source: Financial Accounts-NBR and Statistical Yearbook;

8. Calculation formula:

$$
\text { Cie }=\frac{\left(\frac{\Delta \mathrm{ECF}}{\mathrm{ECF}_{b}}\right)}{\left(\frac{\Delta \mathrm{VBP}_{b}}{\mathrm{VBP}_{b}}\right)}
$$

where " $b$ " means the basic period.

9. Explanations of the previous notation:

- $\quad \mathrm{ECF}=$ total savings, through financial instruments of any kind, made by the population during the year, in the form of their banking and financial assets, constituting the total financial receivables of the population (CTP).

- $\mathrm{GNP}=$ total monetary income obtained by the population, for periods of one year, from any available source, such as income of any monetary nature, but also other liquidity available during the year.

10. Economic significance: it is an indicator of flow; the indicator highlights, through flows, the degree of saving of the monetary incomes of the population and, implicitly, the dynamics of its financial potential, being useful for the knowledge and design of the banking and financial policies.

11. Utility in economic analysis: allows the analysis of the willingness to save of the population, being useful for the correlative analysis with the indicators of income, consumption of the population, and with the banking indicators specific to the population, of the dynamics of saving and investment potential of the population.

12. How to use in the paper: the indicator can be correlated with other generic indicators of saving and financial indebtedness of the population, but also with indicators specific to the financial status of the population; at the same time, the indicator can be integrated into the network of indicators for assessing the financial status of the population, which highlights their interconnections and co-determinations in the perspective of a complex synthetic evaluation indicator.

Indicator 3 (calculation procedure)

Section: I. Financial macroeconomics;

1. Chapter: 4. Assessing the financial status of the population;

2. Paragraph: 4.3. Evaluation of the saving structure;

3. Name: The coefficient of financial indebtedness of the population;

4. Symbol: Cip;

5. Degree of synthesis: derived indicator;

6. Data source: Financial Accounts-NBR and Statistical Yearbook; 
7. Calculation formula:

$$
\text { Cip }=\frac{\text { DTP }}{\text { POP }}
$$

8. Explanations of the previous notation:

- $\quad$ DTP = total financial debts of the population, regardless of nature (banking or nonbanking), instrument and institution, recorded at the end of the year.

- $\quad \mathrm{POP}=$ total population: a group of individuals gathered through citizenship ties and by establishing domicile on the territory of the state, in relation to which the latter exercises its sovereign power the entire data set from which a sample is selected and in connection with which the auditor wants to formulate his conclusions, statistically being evaluated at the end of the year, according to the data from the Statistical Yearbook.

9. Economic significance: the indicator highlights the financial debt per inhabitant, the indebtedness of the population, which depends, first of all, on the quality of the financial system and the level of income and the purchasing power of the population; the indicator can be determined on stock or on flow (debts incurred during the year).

10. Utility in economic analysis: allows the analysis on the whole, but also on types of indebtedness (through indicators derived from detail) of the indebtedness capacity of the population and the comparative analysis in time or space.

11. How to use in the paper: the indicator can be correlated with other generic indicators of saving and financial indebtedness of the population, but also with indicators specific to the financial status of the population; at the same time, the indicator can be integrated into the network of indicators for evaluating the financial status of the population, which highlights their interconnections and co-determinations in the perspective of a complex synthetic evaluation indicator.

Indicator 4 (calculation procedure)

1. Section: I. Financial macroeconomics;

2. Chapter: 4. Assessing the financial condition of the population;

3. Paragraph: 4.3. Evaluation of the saving structure;

4. Name: Population income financing rate;

5. Symbol: Rf;

6. Degree of synthesis: derived indicator;

7. Data source: Financial Accounts-NBR and National Accounts-INS;

8. Calculation formula:

$$
\mathrm{Rf}=\frac{\mathrm{CTP}+\mathrm{DTP}}{\mathrm{VDB}} \times 100
$$

9. Explanations of the previous notation:

- $\quad \mathrm{CTP}=$ financial saving, the total financial receivables of the population, regardless of nature, instrument, and institution.

- $\quad \mathrm{DTP}=$ total financial debts of the population, regardless of nature (banking or nonbanking), instrument and institution, recorded at the end of the year.

- $\quad \mathrm{VDB}=$ income account balance and measures the part of the created value that the population has for final consumption and gross economy (from which it achieves financial savings).

10. Economic significance: the indicator highlights the level of financing of the primary incomes of the population, as debtor and creditor, on the financial-banking markets, which depends generically on its disposable income, and which contains elements for the purchase of financial saving and guarantee instruments of committed loans.

11. Utility in economic analysis: allows the overall and structural analysis of the level of financing of the population, the degree of employment, and the ability to repay and purchase financial assets, providing information for detailed analysis, through specific indicators, of the financial situation of the population.

12. How to use in the paper: the indicator can be correlated with other generic indicators of saving and financial indebtedness of the population, but also with indicators specific 
to the financial status of the population; the indicator makes the connection between the economic and the financial indicators of the evaluation of the households, as an economic agent; at the same time, the indicator can be integrated into the network of indicators for assessing the financial status of the population, which highlights their interconnections and co-determinations in the perspective of a complex synthetic evaluation indicator.

Indicator 5 (calculation procedure)

1. Section: I. Financial macroeconomics;

2. Chapter: 4. Assessing the financial condition of the population;

3. Paragraph: 4.3. Evaluation of the saving structure;

4. Name: Coefficient of financial financing capacity of the population;

5. Symbol: Cdf;

6. Degree of synthesis: derived indicator;

7. Data source: Financial Accounts-NBR and National Accounts-INS;

8. Calculation formula:

$$
\mathrm{Cdf}=\frac{\mathrm{CNP}}{\mathrm{AFP}}
$$

9. Explanations of the previous notation:

- $\quad \mathrm{CNP}=$ represents the net financing capacity of the population, as the difference between the financial assets, the financial receivables of the population, and its financial debts, the difference can be, usually, positive, but sometimes also negative, signifying a need to finance the population.

- $\mathrm{AFP}=$ financial assets available to the population at a given time, regardless of nature, maturity, degree of risk, and forms of ownership; it is also called the financial wealth of the population; is both a flow and a stock indicator, representing the receivables of the population in the form of bank investments, IPB, or financial investments, IPF, that is, cash, demand deposits, term deposits, short-term securities, long-term securities, loans, and others;

10. Economic significance: the indicator expresses the size and meaning of the balance between the financial assets and liabilities of the population in relation to its gross financial assets, highlighting the degree of availability of the financial resources of the population to finance other sectors.

11. Utility in economic analysis: allows the analysis of how to integrate the population in the financial circuit of the economy, its financial effort to finance the economy from its annual financial surplus and taking into account its active financial potential.

12. How to use in the paper: the indicator can be correlated with other generic indicators of saving and financial indebtedness of the population, but also with indicators specific to the financial status of the population; the indicator makes the connection between the financial indicators of the financial evaluation of the economy; at the same time, the indicator can be integrated into the network of indicators for assessing the financial status of the population, which highlights their interconnections and co-determinations in the perspective of a complex synthetic evaluation indicator.

Indicator 6 (calculation procedure)

1. Section: I. Financial macroeconomics;

2. Chapter: 4. Assessing the financial condition of the population;

3. Paragraph: 4.2. Evaluation of the medium- and long-term financing structure;

4. Name: Rate of financial employment of the population;

5. Symbol: Rap;

6. Degree of synthesis: derived indicator;

7. Data source: Financial Accounts-NBR and National Accounts-INS;

8. Calculation formula:

$$
\text { Rap }=\frac{\mathrm{DTP}}{\mathrm{AFP}} \times 100
$$

9. Explanations of the previous notation: 
- $\quad$ DTP = total financial debt of the population, regardless of the nature (banking or non-banking) instrument and institution, recorded at the end of the year.

- $\mathrm{AFP}=$ financial assets available to the population at a given time, regardless of nature, maturity, degree of risk, and forms of ownership; it is also called the financial wealth of the population; is both a flow and a stock indicator, representing the receivables of the population in the form of bank investments, IPB, or financial investments, IPF, that is, cash, demand deposits, term deposits, short-term securities, long-term securities, loans, and others.

10. Economic significance: the indicator expresses, through the ratio of financial debts to financial assets, the degree of indebtedness of the population according to its financial potential, constituting a relative indicator of the participation, passive or active, of the population in financial relations in the economy.

11. Utility in economic analysis: allows the analysis of medium- and long-term financial capacity, which complements the monetary (liquid) capacity of the population to borrow, allowing detailed analysis, by breaking down the two absolute indicators into components; at the same time, it offers the possibility of dynamic analysis but also of the elasticity towards different correlative indicators, such as the saving indicator, banking indicator, etc.

12. How to use in the paper: the indicator can be correlated with other generic indicators of saving and financial indebtedness of the population, but also with indicators specific to the financial situation of the population, especially the long-term and shortterm financial situation; at the same time, the indicator makes the connection between the economic and the financial indicators of the evaluation of the households, as an economic agent; at the same time, the indicator can be integrated into the network of indicators for assessing the financial status of the population, which highlights their interconnections and co-determinations in the perspective of a complex synthetic evaluation indicator.

\section{Results and Discussion}

The calculation of the absolute primary indicators in the period 2007-2019 was performed based on the existing data in the Financial Accounts of the National Bank of Romania and the National Accounts of the National Institute of Statistics.

Calculation of the values of the absolute primary indicators:

The realized values of the absolute primary indicators (Table 1), based on the values of the 16 relevant relative indicators that characterize the financial status of the population, for the years of the analyzed period, were presented in the table below.

According to the Table below, in 2019, the primary indicators registered mainly higher values compared to the previous year. There are also indicators with values lower than 2018, respectively, Bank deposits of the population, Financial saving, Gross formation of fixed capital of the population, Interest rate received by the population on savings instruments, Financial investments of the population, Population (for the indicator "Population" we recalculated the value for the years 2017 and 2018, according to the Press Release no. 77/19 March 2020, INS. By default, the values of the dependent indicators, the Income and Money Expenditures of the population (GNP and CHB) registered small changes for the mentioned years).

The population's financial assets increased in 2019, influenced mainly by cash and deposits (the main financial receivable of the population) and the increase of the stock of the "other receivables" component (due to the increase in the flow of operations such as participation interests, equity transactions, as well as shareholder transactions).

Financial assets in the category of loans granted by households increased, mainly due to the acquisition of government securities under the "Treasury" program issued by the Ministry of Public Finance in 2019 [33]. 
Table 1. The evolution of the primary indicators regarding the characterization of the financial status of the population in the period 2007-2019.

\begin{tabular}{|c|c|c|c|c|c|c|c|c|c|c|c|c|c|c|}
\hline Indicator & UM & 2007 & 2008 & 2009 & 2010 & 2011 & 2012 & 2013 & 2014 & 2015 & 2016 & 2017 & 2018 & 2019 \\
\hline AFP s & mil.lei & 410,503 & 413,696 & 334,346 & 337,052 & 349,705 & 416,456 & 538,323 & 641,026 & 675,641 & 720,233 & 770,649 & 738,759 & 919,817 \\
\hline AFP f & mil.lei & 32,457 & 144,882 & -8349 & 25,885 & 70,943 & 83,271 & 103,083 & 20,327 & 137,318 & 44,592 & 50,416 & $-31,890$ & 181,058 \\
\hline AFE f & mil.lei & 291,730 & 331,335 & 148,074 & 126,276 & 197,748 & 159,740 & 89,456 & 16,902 & 46,308 & 110,372 & 82,474 & 64,146 & 320,653 \\
\hline ALC s & mil.lei & 78,920 & 97,462 & 109,002 & 117,502 & 129,722 & 137,460 & 149,317 & 161,737 & 176,782 & 202,739 & 222,592 & 239,304 & 272,803 \\
\hline $\mathrm{CHB}$ & mil.lei & 136,480 & 143,443 & 153,427 & 154,003 & 158,928 & 165,379 & 173,291 & 183,398 & 209,825 & 254,450 & 263,114 & 347,072 & 392,497 \\
\hline CHD & mil.lei & 8766 & 12,890 & 12,078 & 10,544 & 10,367 & 8665 & 8068 & 6660 & 6147 & 6379 & 7241 & 7531 & 9767 \\
\hline CNE f & mil.lei & $-49,277$ & $-55,186$ & $-23,108$ & $-18,155$ & $-28,041$ & -8334 & 7471 & 13,488 & 14,683 & -4096 & $-17,518$ & $-14,515$ & $-10,492$ \\
\hline CNP f & mil.lei & 8701 & 13,650 & 21,321 & 32,435 & 26,139 & 46,223 & 90,559 & 16,106 & 11,800 & 64,151 & $-22,287$ & 25,056 & 26,135 \\
\hline CRP s & mil.lei & 80,460 & 113,589 & 116,452 & 120,195 & 121,578 & 122,628 & 122,130 & 120,513 & 107,953 & 113,037 & 114,283 & 119,436 & 160,000 \\
\hline CTP s & mil.lei & 410,503 & 413,698 & 334,345 & 290,620 & 313,666 & 370,742 & 461,740 & 493,591 & 516,051 & 563,012 & 584,969 & 624,747 & 680,974 \\
\hline DTP s & mil.lei & 101,479 & 137,544 & 137,835 & 151,112 & 158,433 & 163,460 & 165,072 & 161,484 & 151,870 & 189,838 & 205,594 & 219,986 & 233,185 \\
\hline DEP s & mil.lei & 64,990 & 80,518 & 94,930 & 105,388 & 113,068 & 123,595 & 132,287 & 139,559 & 146,780 & 163,462 & 178,660 & 241,686 & 222,399 \\
\hline ECF s & mil.lei & 281,719 & 268,151 & 267,400 & 258,937 & 275,787 & 329,856 & 412,876 & 436,677 & 456,547 & 499,919 & 530,414 & 534,176 & 532,039 \\
\hline FBP & mil.lei & 8284 & 9284 & 9625 & 29,886 & 30,836 & 33,345 & 35,348 & 34,333 & 35,206 & 34,044 & 36,053 & 37,098 & 36,913 \\
\hline IPF & mil.lei & 236,389 & 220,124 & 245,714 & 133,568 & 130,908 & 163,880 & 157,090 & 139,319 & 133,049 & 123,137 & 155,152 & 192,389 & 236,638 \\
\hline IVF $\mathrm{f}$ & mil.lei & 27,248 & 37,814 & 26,599 & 23,217 & 25,049 & 19,325 & 7155 & 1101 & 7987 & 58,169 & 55,870 & 41,954 & 48,223 \\
\hline PFE $\mathrm{f}$ & mil.lei & 211,552 & 156,639 & 90,358 & 75,978 & 102,196 & 77,445 & 99,516 & 25,177 & 46,989 & 151,464 & 71,223 & 22,234 & 36,949 \\
\hline PFP f & mil.lei & 29,592 & 28,140 & -1738 & -4442 & 1478 & 563 & 665 & 2556 & 6674 & 14,429 & 12,191 & 15,739 & 13,339 \\
\hline PIB & mil.lei & 416,007 & 514,007 & 501,139 & 533,881 & 565,097 & 595,367 & 637,456 & 668,590 & 712,588 & 765,135 & 856,727 & 940,478 & $1,059,803$ \\
\hline POP & mii & 22,562 & 22,542 & 22,516 & 22,481 & 22,434 & 22,391 & 22,346 & 22,298 & 22,242 & 22,223 & 22,215 & 22,197 & 22,175 \\
\hline Rdp & $\%$ & 13.30 & 15.80 & 17.30 & 14.11 & 14.00 & 13.26 & 11.32 & 9.47 & 5.69 & 5.64 & 5.93 & 5.94 & 7.69 \\
\hline Rdi & $\%$ & 6.70 & 9.55 & 11.89 & 7.29 & 6.24 & 5.31 & 4.00 & 2.92 & 1.24 & 0.60 & 0.69 & 2.14 & 1.97 \\
\hline VDB & mil.lei & 251,208 & 330,147 & 313,038 & 321,980 & 324,227 & 336,621 & 448,548 & 470,408 & 426,795 & 434,358 & 492,590 & 611,554 & 667,122 \\
\hline GNP & mil.lei & 200,549 & 265,161 & 279,977 & 276,993 & 255,752 & 171,336 & 180,202 & 250,692 & 239,711 & 296,852 & 310,832 & 400,611 & 458,224 \\
\hline
\end{tabular}

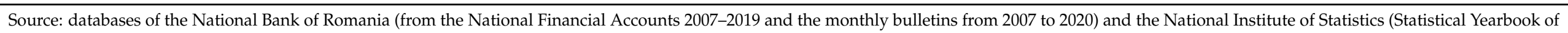
Romania, editions 2007-2019, Monthly Statistical Bulletin from December 2007-2020), Report on financial stability, 2020, NBR, Bucharest. 
Regarding the financial commitments of the population, they increased in 2019, compared to the previous year, the main financial commitments being loans and other amounts to be paid. The share of loans contracted by households in GDP decreased in 2019, compared to 2018, a cause being the NBR Regulation no. 6/2018 [34] for the amendment and completion of the Regulation of the National Bank of Romania no. 17/2012 [35] on some credit conditions, with subsequent amendments and completions, which establishes a debt ceiling for loans granted to individuals (measure applied since the beginning of 2019). The share of loans in the total financial commitments of the sector had a similar trend.

The values of the relevant relative indicators that characterize the financial status of the population.

Indicator 1: Rate of financial savings of the population (Ref).

It highlights the degree of financial saving of the population, in other words, the degree of financial capitalization, the formation of the financial wealth of the population, being influenced by the evolution of population income, interest rates and dividends, and the development of the banking system (Table 2).

Table 2. The evolution of the financial saving rate in the period 2007-2019.

\begin{tabular}{cccccccccccccccccccccc}
\hline \multirow{2}{*}{ Indicator } & \multicolumn{10}{c}{ Period } & \multicolumn{10}{c}{} \\
\cline { 2 - 13 } & U.M. & $\mathbf{2 0 0 7}$ & $\mathbf{2 0 0 8}$ & $\mathbf{2 0 0 9}$ & $\mathbf{2 0 1 0}$ & $\mathbf{2 0 1 1}$ & $\mathbf{2 0 1 2}$ & $\mathbf{2 0 1 3}$ & $\mathbf{2 0 1 4}$ & $\mathbf{2 0 1 5}$ & $\mathbf{2 0 1 6}$ & $\mathbf{2 0 1 7}$ & $\mathbf{2 0 1 8}$ & $\mathbf{2 0 1 9}$ \\
\hline ECF s & mil. lei & 281,719 & 268,151 & 267,400 & 258,937 & 275,787 & 329,856 & 412,876 & 436,677 & 456,547 & 499,919 & 530,414 & 534,176 & 532,039 \\
\hline GDP & mil.lei & 416,007 & 514,007 & 501,139 & 533,881 & 565,097 & 595,367 & 637,456 & 668,590 & 712,588 & 765,135 & 856,727 & 940,478 & $1,059,803$ \\
\hline Ref & $\%$ & 67.72 & 52.17 & 53.36 & 48.50 & 48.80 & 55.40 & 64.77 & 65.31 & 64.07 & 65.34 & 61.91 & 56.79 & 50.20 \\
\hline
\end{tabular}

Source: databases of the National Bank of Romania (from the National Financial Accounts 2007-2019 and the monthly bulletins from 2007 to 2020) and the National Institute of Statistics (Statistical Yearbook of Romania, editions 2007-2020, Monthly statistical bulletin from December 2007-2019).

Determination of the indicator for the analyzed period:

In the analyzed period there is a decreasing trend of the level of this indicator, at the end of 2019, it has a value 6.60 pp lower than in 2018, and maintains a decreasing rate similar to that of 2018 compared to 2017 , respectively by 5, $11 \mathrm{pp}$. It is obvious that the population's investments in financial securities were mainly determined by the revenues generated by the gradual development of the Bucharest Stock Exchange and by the impact of the financial crisis. The indicator can be divided into types of financial savings and can be correlated with indicators specific to the financial situation of the population, calculated below (Figure 1).

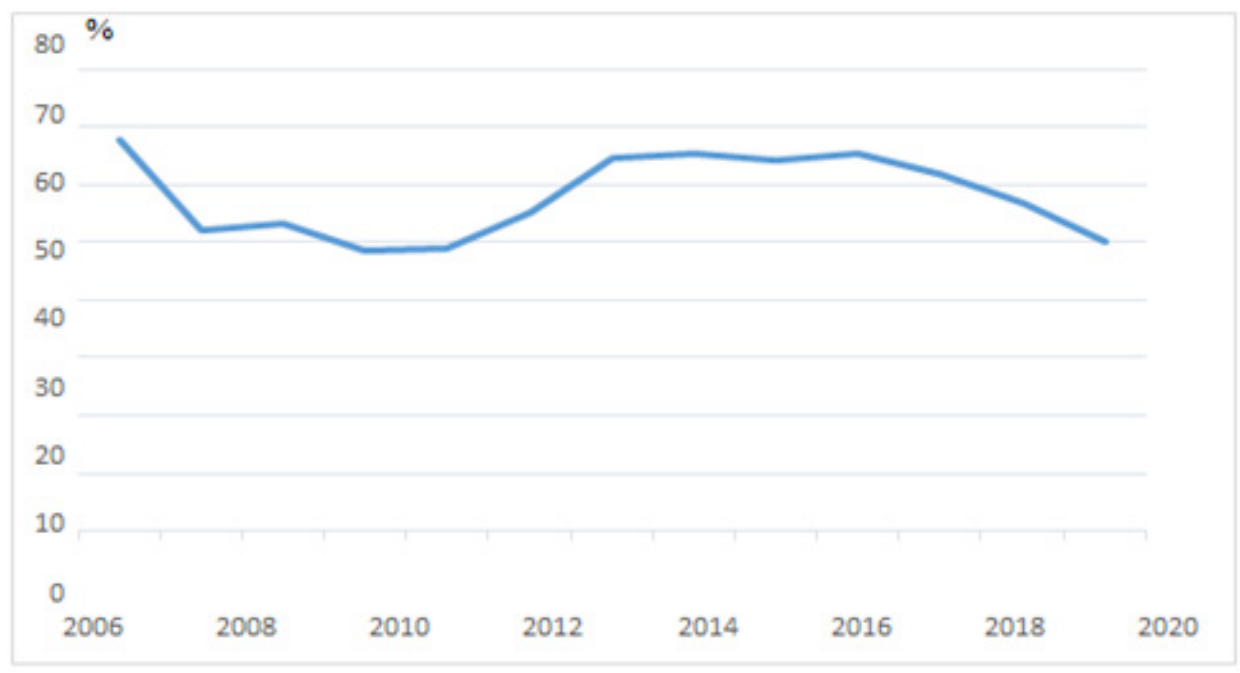

\section{financial savings rate}

Figure 1. Evolution of the financial saving rate of the population in the period 2007-2019. Source: databases of the National Bank of Romania (from the National Financial Accounts 2007-2019 and the monthly bulletins from 2007 to 2020) and the National Institute of Statistics (Statistical Yearbook of Romania, editions 2007-2020, Monthly statistical bulletin from December 2007-2019). 
Indicator 2: Population saving coefficient (Cie).

Determination of the indicator for the analyzed period:

The evolution of the level of this indicator highlights two phenomena: in certain periods $(2008,2009,2011,2012,2015$, and 2019) the coefficient of the increase in the saving was exceeded by the coefficient of increase in the monetary incomes, because in other periods $(2007,2010,2013,2014,2016,2017,2018)$ the financial saving to register an increased coefficient of saving was much higher than that of money income (Table 3 ).

Table 3. The evolution of the coefficient of inclination towards saving in the period 2007-2019.

\begin{tabular}{|c|c|c|c|c|c|c|c|c|c|c|c|c|c|c|}
\hline \multirow{2}{*}{ Indicator } & \multicolumn{13}{|c|}{ Period } & \multirow[b]{2}{*}{2019} \\
\hline & U.M. & 2007 & 2008 & 2009 & 2010 & 2011 & 2012 & 2013 & 2014 & 2015 & 2016 & 2017 & 2018 & \\
\hline ECF & mil.lei & 281,719 & 268,151 & 267,400 & 258,937 & 275,787 & 329,856 & 412,876 & 436,677 & 456,547 & 499,919 & 530,414 & 534,176 & 532,039 \\
\hline GNP & mil.lei & 200,549 & 265,161 & 279,977 & 276,993 & 255,752 & 171,336 & 180,202 & 250,692 & 239,711 & 296,852 & 310,832 & 400,611 & 458,224 \\
\hline$\triangle \mathrm{ECF}$ & mil.lei & 56,149 & $-13,568$ & -751 & -8463 & 16,850 & 54,069 & 83,020 & 23,801 & 19,870 & 43,372 & 30,495 & 3762 & -2137 \\
\hline$\triangle \mathrm{VBP}$ & mil.lei & 1991 & 64,612 & 14,816 & -2984 & $-21,241$ & $-84,416$ & 8866 & 70,490 & $-10,981$ & 57,141 & 13,686 & 89,604 & 57,613 \\
\hline$\Delta \mathrm{ECF} / \mathrm{ECF}_{b}$ & $\%$ & 0.25 & -0.05 & 0.00 & -0.03 & 0.07 & 0.20 & 0.25 & 0.06 & 0.05 & 0.10 & 0.70 & 0.12 & -0.56 \\
\hline$\Delta \mathrm{VBP} / \mathrm{VBP}_{b}$ & $\%$ & 0.01 & 0.32 & 0.06 & -0.01 & -0.08 & -0.33 & 0.05 & 0.39 & -0.04 & 0.24 & 0.23 & 6.55 & 0.64 \\
\hline Cie & $\%$ & 25.00 & -0.16 & -0.05 & 3.00 & -0.88 & -0.61 & 5.00 & 0.15 & -1.25 & 0.42 & 3.04 & 0.02 & -0.88 \\
\hline
\end{tabular}

Source: databases of the National Bank of Romania (from the National Financial Accounts 2007-2019 and the monthly bulletins from 2007 to 2020) and the National Institute of Statistics (Statistical Yearbook of Romania, editions 2007-2020, Monthly statistical bulletin from December 2007-2019).

Although there was a reduction in the increase in the money income of the population in 2019 compared to 2018, respectively from 6.55 to 0.64 , the coefficient of increase reduced from 0.32 to 0.22 , in the period $2007-2018$, the saving of the population, reflected by the increase coefficient of saving, has decreased recently (reaching a negative minimum of $(-0.44)$ in 2019 compared to 2018), and the coefficient of propensity to save the population has decreased from 25.00 (in 2007 compared to 2006) reaching a negative minimum of (-0.88) for 2019 compared to 2018. At the same time, it will be found, through other indicators, which the degree of indebtedness of the population will increase (Figure 2).

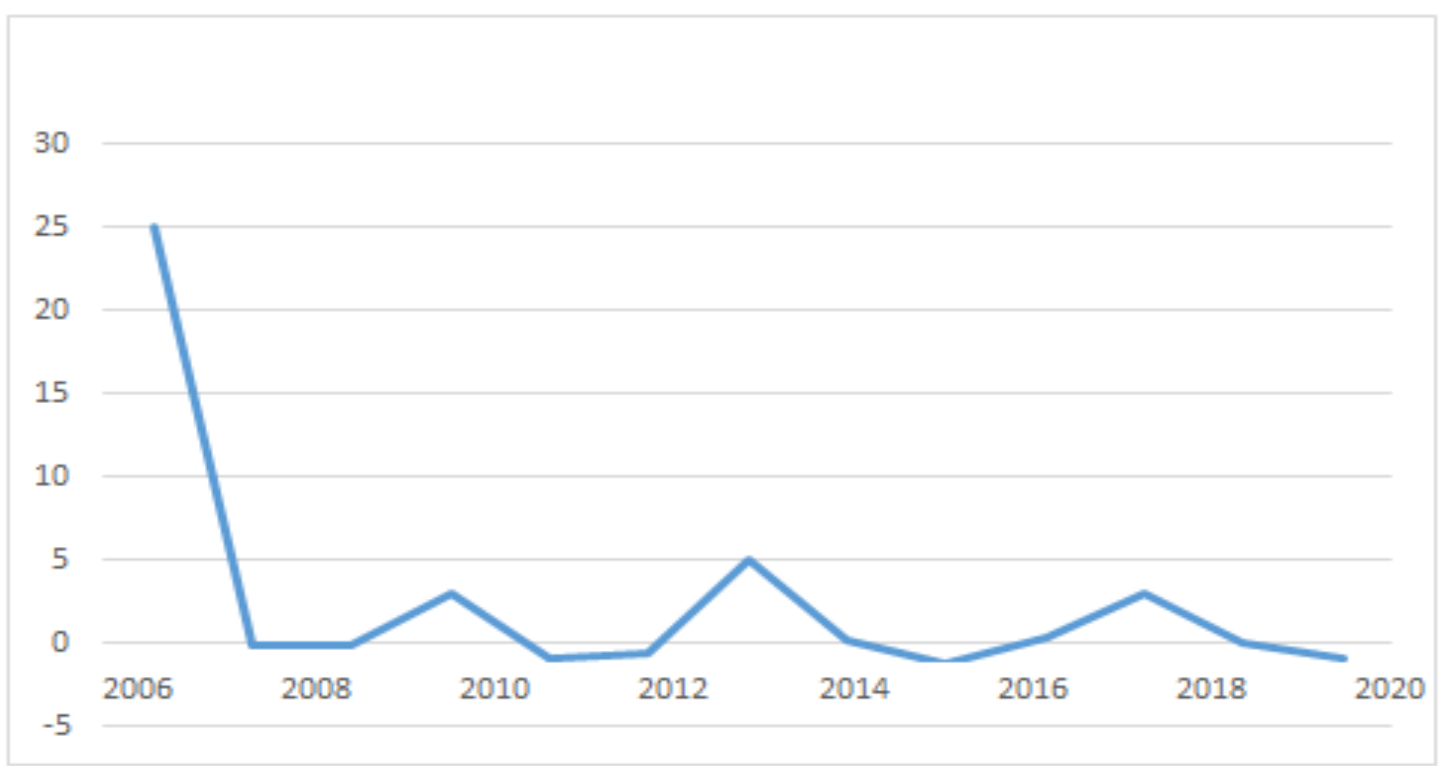

coefficient of inclination towards saving the population

Figure 2. Evolution of the coefficient of inclination towards saving the population in the period 2007-2019. Source: databases of the National Bank of Romania (from the National Financial Accounts 2007-2019 and the monthly bulletins from 2007 to 2020) and the National Institute of Statistics (Statistical Yearbook of Romania, editions 2007-2020, Monthly statistical bulletin from December 2007-2019). 
Indicator 3: Coefficient of indebtedness of the population (Cip).

Determination of the indicator for the analyzed period.

It was found that the indebtedness of the population, expressed per capita, increased significantly, but we must also take into account the effect of inflation, in nominal terms the degree of indebtedness increasing, during the analyzed period the evolution of the indebtedness coefficient increased to $10.52 \mathrm{pp}$, respectively with $0.91 \mathrm{pp}$ in 2019 compared to 2018 (Table 4).

Table 4. The evolution of the indebtedness coefficient in the period 2007-2019.

\begin{tabular}{ccccccccccccccccccc}
\hline \multirow{2}{*}{ Indicator } & \multicolumn{10}{c}{ Period } \\
\cline { 2 - 12 } & U.M. & $\mathbf{2 0 0 7}$ & $\mathbf{2 0 0 8}$ & $\mathbf{2 0 0 9}$ & $\mathbf{2 0 1 0}$ & $\mathbf{2 0 1 1}$ & $\mathbf{2 0 1 2}$ & $\mathbf{2 0 1 3}$ & $\mathbf{2 0 1 4}$ & $\mathbf{2 0 1 5}$ & $\mathbf{2 0 1 6}$ & $\mathbf{2 0 1 7}$ & $\mathbf{2 0 1 8}$ & $\mathbf{2 0 1 9}$ \\
\hline DTP & mil.lei & 101,479 & 137,544 & 137,835 & 151,112 & 158,433 & 163,460 & 165,072 & 161,484 & 151,870 & 189,838 & 205,594 & 219,986 & 233,185 \\
\hline POP & $\begin{array}{c}\text { thousands of } \\
\text { inhabitants }\end{array}$ & 22,562 & 22,542 & 22,516 & 22,481 & 22,434 & 22,391 & 22,346 & 22,298 & 22,242 & 22,223 & 22,215 & 22,197 & 22,175 \\
\hline Cip & $\begin{array}{c}\text { Thousands } \\
\text { lei/inha- } \\
\text { bitants(\%) }\end{array}$ & 4.50 & 6.10 & 6.12 & 6.72 & 7.06 & 7.30 & 7.39 & 7.24 & 6.83 & 8.54 & 9.25 & 9.91 & 10.52 \\
\hline
\end{tabular}

Source: databases of the National Bank of Romania (from the National Financial Accounts 2007-2019 and the monthly bulletins from 2007 to 2020) and the National Institute of Statistics (Statistical Yearbook of Romania, editions 2007-2020, Monthly statistical bulletin from December 2007-2019).

The evolution of this indicator must be correlated with the evolution of interest rates, the purchasing power of the population, and other financial indicators of the population, the indicator highlighting the borrowing capacity of the population, but also the quality of the banking and financial system (Figure 3).

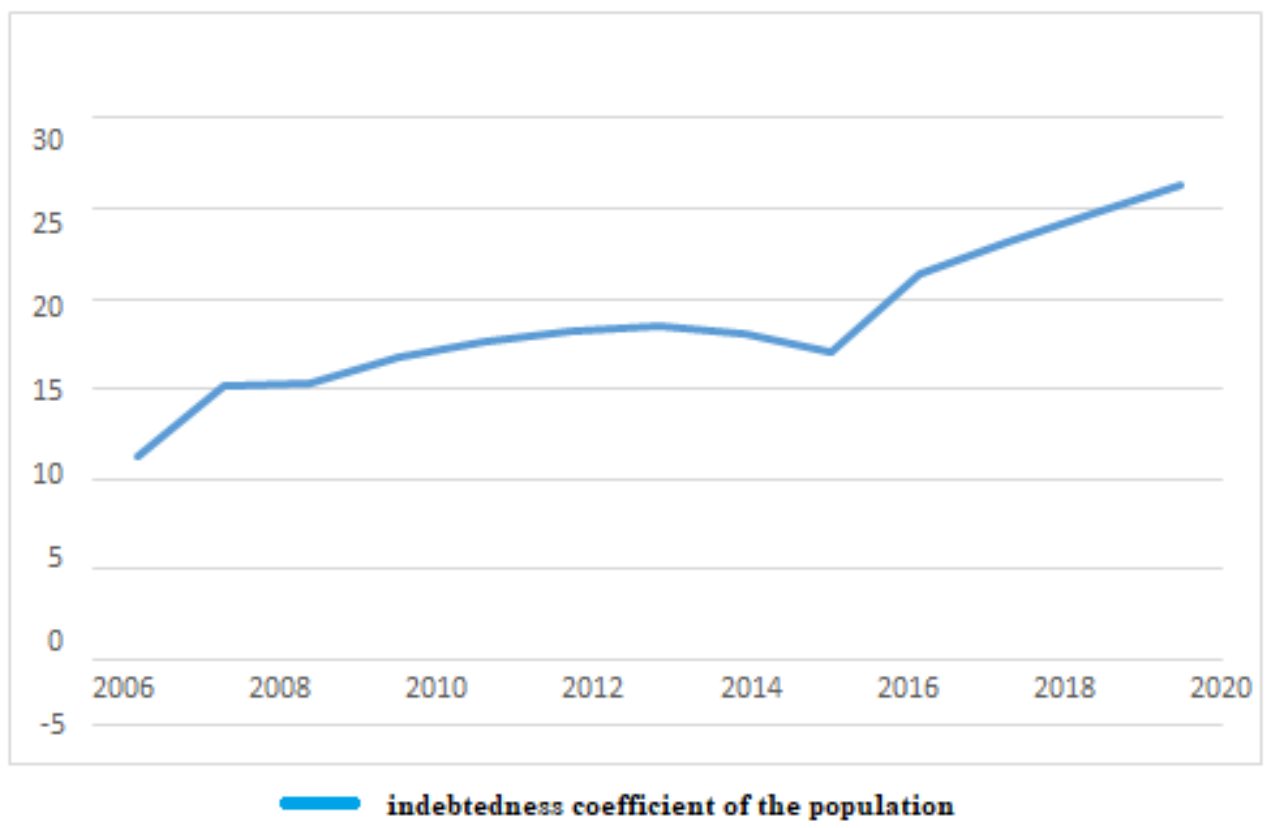

Figure 3. The evolution of the indebtedness coefficient of the population in the period 2007-2019. Source: databases of the National Bank of Romania (from the National Financial Accounts 2007-2019 and the monthly bulletins from 2007 to 2020) and the National Institute of Statistics (Statistical Yearbook of Romania, editions 2007-2020, Monthly statistical bulletin from December 2007-2019).

Indicator 4: Population income financing rate (Rfz).

Determination of the indicator for the analyzed period:

The indicator highlights, for the analyzed period, the decrease in the degree of involvement of the population incomes on the banking and financial markets, the minimum point being reached in 2019 , when the rate decreased to $137.03 \%$, at approximately the same level registered in 2010 , to $137,19 \%$, the trend reflecting the effects of the financial crisis. In the 
period 2014-2018 there is a significant recovery, the level reached in 2016 being $173.32 \%$, but lower than in 2007, when the value was $203.81 \%$, but decreasing in 2017 compared to 2018 by 12.83 pp, which could be a negative signal for the banking and financial markets in terms of household income (Table 5).

Table 5. Evolution of the population income financing rate in the period 2007-2019.

\begin{tabular}{|c|c|c|c|c|c|c|c|c|c|c|c|c|c|c|}
\hline \multirow{2}{*}{ Indicator } & \multicolumn{13}{|c|}{ Period } & \multirow[b]{2}{*}{2019} \\
\hline & U.M. & 2007 & 2008 & 2009 & 2010 & 2011 & 2012 & 2013 & 2014 & 2015 & 2016 & 2017 & 2018 & \\
\hline CTP s & mil.lei & 410,503 & 413,698 & 334,345 & 290,620 & 313,666 & 370,742 & 461,740 & 493,591 & 516,051 & 563,012 & 584,969 & 624,747 & 680,974 \\
\hline DTP s & mil.lei & 101,479 & 137,544 & 137,835 & 151,112 & 158,433 & 163,460 & 165,072 & 161,484 & 151,870 & 189,838 & 205,594 & 219,986 & 233,185 \\
\hline $\mathrm{CTP}+\mathrm{DTP}$ & mil.lei & 511,982 & 551,242 & 472,180 & 441,732 & 472,099 & 534,202 & 626,812 & 655,075 & 667,921 & 752,850 & 790,563 & 844,733 & 914,159 \\
\hline VDB & mil.lei & 251,208 & 330,147 & 313,038 & 321,980 & 324,227 & 336,621 & 448,548 & 470,408 & 426,795 & 434,358 & 492,590 & 611,554 & 667,122 \\
\hline Rfz & $\%$ & 203.81 & 166.97 & 150.84 & 137.19 & 145.61 & 158.70 & 139.74 & 139.26 & 156.50 & 173.32 & 160.49 & 138.12 & 137.03 \\
\hline
\end{tabular}

Source: databases of the National Bank of Romania (from the National Financial Accounts 2007-2019 and the monthly bulletins from 2007 to 2020) and the National Institute of Statistics (Statistical Yearbook of Romania, editions 2007-2020, Monthly statistical bulletin from December 2007-2019).

Correlated with the evolution of the indicator Income banking rate (Rbv), the evolution of the Rfz indicator highlights the evolution of the population income involvement in banking and financial flows, the degree of employment of the population in activities in banking and financial markets, allowing knowledge of the state and evolution of financial behavior for the forecasting and design of this indicator, as well as for the elaboration of monetary policies (Figure 4).

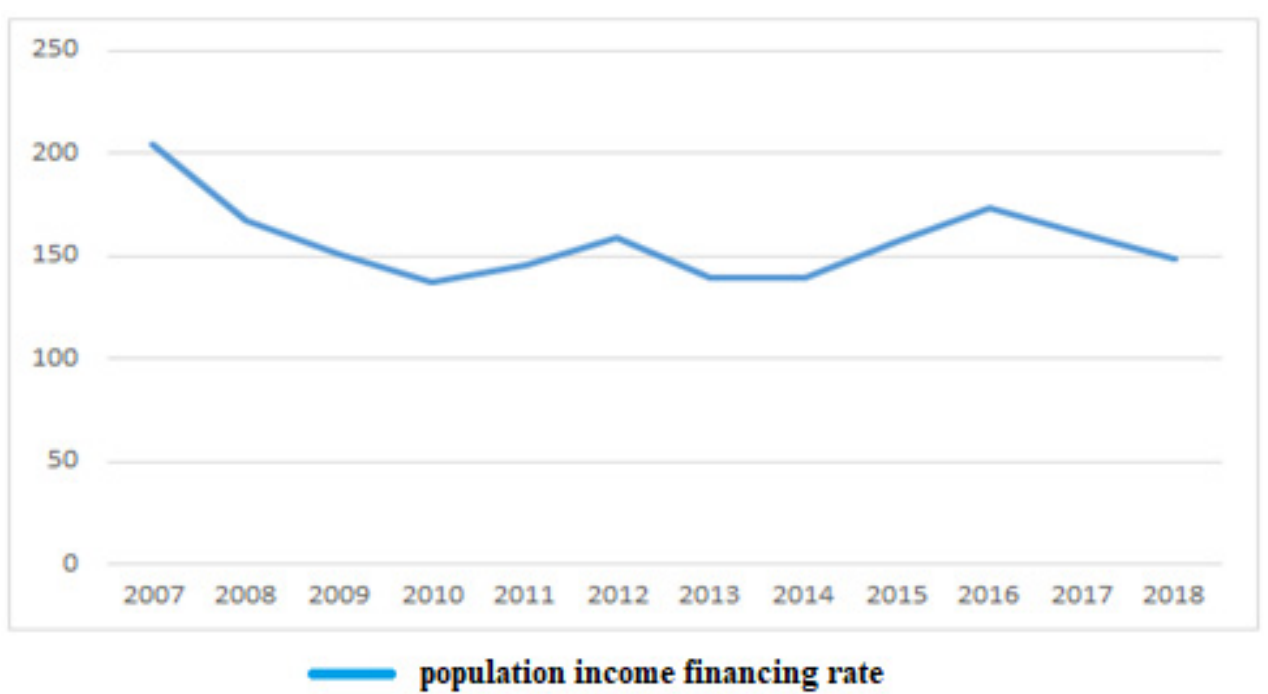

Figure 4. Evolution of the population income financing rate. Source: databases of the National Bank of Romania (from the National Financial Accounts 2007-2019 and the monthly bulletins from 2007 to 2020) and the National Institute of Statistics (Statistical Yearbook of Romania, editions 2007-2020, Monthly statistical bulletin from December 2007-2019).

Indicator 5: Coefficient of financial financing capacity of the population (Cdf).

The evolution of the indicator, calculated on the basis of two primary flow indicators, is ascending, towards predominantly supra-unitary values (except for 2009, 2017, and 2018), under the impact of the increase of CNP values by the increase of AFP values. Also, it was observed that in 2009, AFP had negative absolute values, respectively -2.55 p.p., arithmetically, the value of the coefficient was negative (Table 6). The evolution, as a whole, represents the deterioration of the population's financial capacity, the diminution or depletion of the population's financial resources for financing the other sectors, a situation reflected by the level indicator coefficient of financing the economy by population ( $\mathrm{Cfe}$ ), presented in Figure 5. 
Table 6. Evolution of the financial financing capacity coefficient in the period 2007-2019.

\begin{tabular}{|c|c|c|c|c|c|c|c|c|c|c|c|c|c|c|}
\hline \multirow{2}{*}{ Indicator } & \multicolumn{13}{|c|}{ Period } & \multirow[b]{2}{*}{2019} \\
\hline & U.M. & 2007 & 2008 & 2009 & 2010 & 2011 & 2012 & 2013 & 2014 & 2015 & 2016 & 2017 & 2018 & \\
\hline CNP f & mil.lei & 8701 & 13,650 & 21,321 & 32,435 & 26,139 & 46,223 & 90,559 & 16,106 & 11,800 & 64,151 & $-22,287$ & 25,056 & 26,135 \\
\hline AFP f & mil.lei & 32,457 & 144,882 & -8349 & 25,885 & 70,943 & 83,271 & 103,083 & 20,327 & 137,318 & 44,592 & 50,416 & $-31,890$ & 181,058 \\
\hline Cdf & $\%$ & 0.27 & 0.09 & -2.55 & 1.25 & 0.37 & 0.56 & 0.88 & 0.79 & 0.09 & 1.44 & -0.44 & -0.79 & 0.14 \\
\hline
\end{tabular}

Source: databases of the National Bank of Romania (from the National Financial Accounts 2007-2019 and the monthly bulletins from 2007 to 2020) and the National Institute of Statistics (Statistical Yearbook of Romania, editions 2007-2020, Monthly statistical bulletin from December 2007-2019).

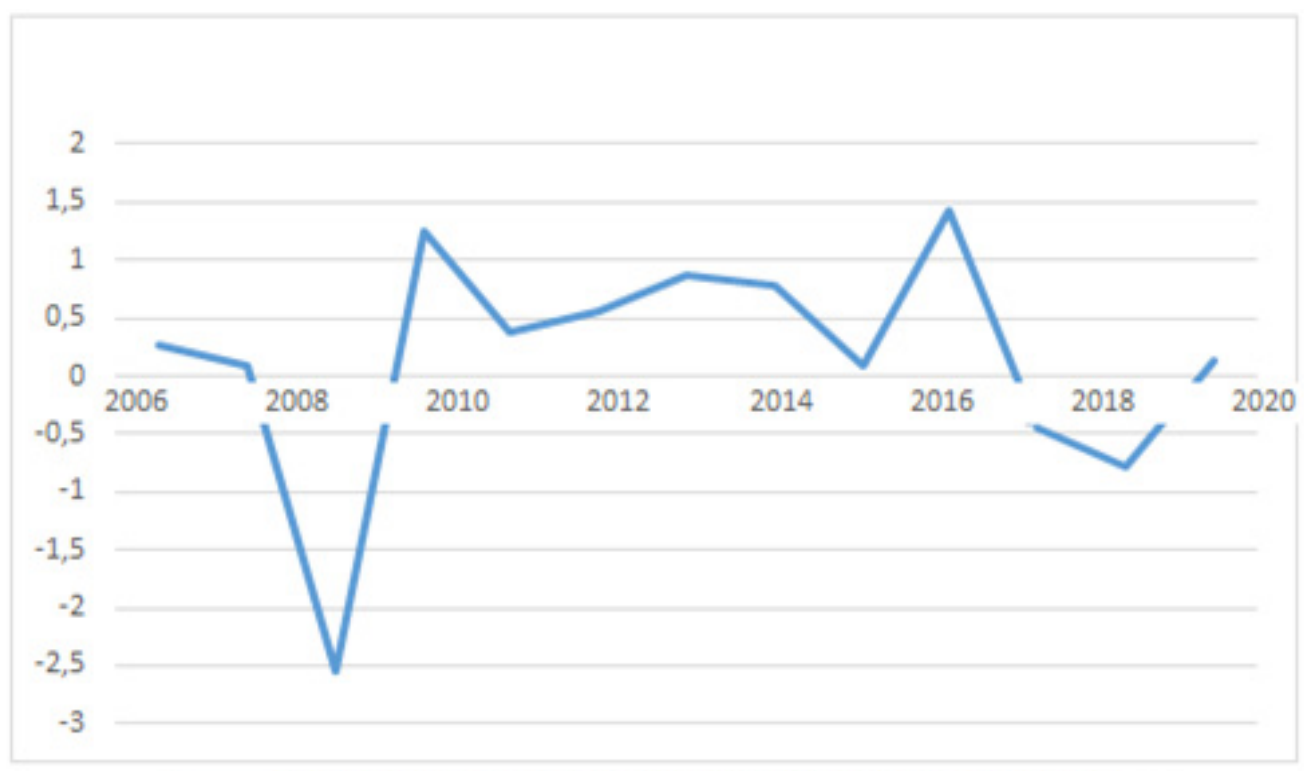

coefficient of financial financing capacity of the population

Figure 5. Evolution of the coefficient of financial financing capacity of the population in the period 2007-2019. Source: databases of the National Bank of Romania (from the National Financial Accounts 2007-2019 and the monthly bulletins from 2007 to 2020) and the National Institute of Statistics (Statistical Yearbook of Romania, editions 2007-2020, Monthly statistical bulletin from December 2007-2019).

At the same time, the evolution of the indicator highlights the fluctuating financial activity of the population, a phenomenon also expressed by other indicators of saving and indebtedness, with indicators of the financial state of the economy as a whole.

Indicator 6: Population financial employment rate (Rap).

Determination of the indicator in the analyzed period:

There is, in general, an increasing evolution of the indicator until 2011, highlighting the financial indebtedness rate of the population (RIT) and the indebtedness coefficient of the population (Cip), the increase of the indebtedness of the population towards the financial system, especially by engaging in bank loans and highlighting the emphasis on the active participation of the population in the financial-banking relations in the economy (Figure 6). After 2011, under the impact of the financial crisis, the degree of the prudence of the population increases, which leads to a reduction of the financial employment rate of the population, to a level very close to that of 2007. 


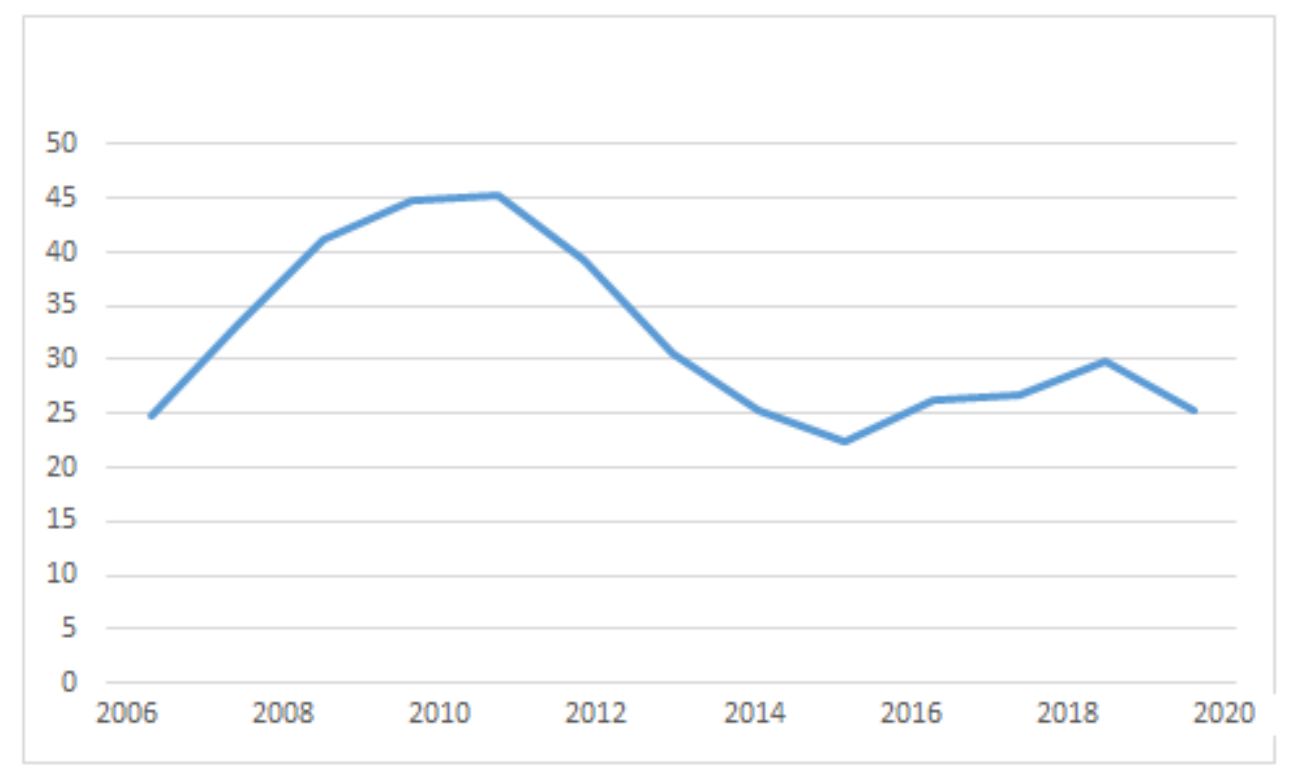

financial employment rate of the population

Figure 6. Evolution of the financial employment rate of the population in the period 2007-2019. Source: databases of the National Bank of Romania (from the National Financial Accounts 2007-2019 and the monthly bulletins from 2007 to 2020) and the National Institute of Statistics (Statistical Yearbook of Romania, editions 2007-2020, Monthly statistical bulletin from December 2007-2019).

At the same time, the evolution of the indicator highlights the reduction of the mediumand long-term financial capacity of the population, correlated, as we will see, with the evolution of the monetary (liquid) capacity of the population to borrow $(\mathrm{Clc})$. During the analyzed period, debts increased by approx. 2.17 times in absolute values (2018 compared to 2007), while financial assets increased by 1.80 times, the growth attenuating starting with 2012, also affected by the crisis globally and on the national financial level. Moreover, the value of the indicator in 2019 approached the value registered in 2007, respectively $25.40 \%$ in 2019 and $24.72 \%$ in 2007, which shows a decrease in the active participation of the population in the financial-banking relations in the economy (Table 7).

Table 7. Evolution of the financial employment rate of the population in the period 2007-2019.

\begin{tabular}{cccccccccccccccccccccc}
\hline \multirow{2}{*}{ Indicator } & \multicolumn{10}{c}{ Period } \\
\cline { 2 - 13 } & U.M. & $\mathbf{2 0 0 7}$ & $\mathbf{2 0 0 8}$ & $\mathbf{2 0 0 9}$ & $\mathbf{2 0 1 0}$ & $\mathbf{2 0 1 1}$ & $\mathbf{2 0 1 2}$ & $\mathbf{2 0 1 3}$ & $\mathbf{2 0 1 4}$ & $\mathbf{2 0 1 5}$ & $\mathbf{2 0 1 6}$ & $\mathbf{2 0 1 7}$ & $\mathbf{2 0 1 8}$ & $\mathbf{2 0 1 9}$ \\
\hline DTP s & mil.lei & 101,479 & 137,544 & 137,835 & 151,112 & 158,433 & 163,460 & 165,072 & 161,484 & 151,870 & 189,838 & 205,594 & 219,986 & 233,185 \\
\hline AFP s & mil.lei & 410,503 & 413,696 & 334,346 & 337,052 & 349,705 & 416,456 & 538,323 & 641,026 & 675,641 & 720,233 & 770,649 & 738,759 & 919,817 \\
\hline Rap & $\%$ & 24.72 & 33.25 & 41.23 & 44.83 & 45.30 & 39.25 & 30.66 & 25.19 & 22.48 & 26.36 & 26.68 & 29.78 & 25.40 \\
\hline
\end{tabular}

Source: databases of the National Bank of Romania (from the National Financial Accounts 2007-2019 and the monthly bulletins from 2007 to 2020) and the National Institute of Statistics (Statistical Yearbook of Romania, editions 2007-2020, Monthly statistical bulletin from December 2007-2019).

In the resulting section, the derived indicators are calculated and represented, being directly related to the novelty of the paper as mentioned in the sections above. Moreover, also in the results of our research, the financial assets in Romania of households have the lowest value of financial assets relative to GDP (only one-third of the EU average in 2019) and are in decreasing evolution, compared to financial assets relative to GDP that increased in the same reference period in the European Union. Moreover, the calculation of these derived indicators can be considered an element of scientific contribution to the literature. For example, by calculating Indicator 1, the financial saving rate of the population (Ref) highlights the degree of financial saving of the population, in other words, the degree of financial capitalization, formation of the financial wealth of the population, is influenced 
by the evolution of population income, interest rates, and dividends, as well as the development of the banking system. These aspects are present in the purpose and objectives of our work.

Primary indicators and derivatives can be used in determining the economic situation of the population of a nation, but especially in determining the state of affairs in terms of population wealth through methods of measuring poverty using a statistical function that combines the threshold of poverty determined by indicators for measuring the well-being of the household [24], poverty incidence-calculated as a percentage of the population that cannot afford to buy the basic basket of goods, with the calculation formula:

$$
H=\frac{\mathrm{q}}{\mathrm{n}}
$$

where: $H$ (headcount index), $\mathrm{n}$-represents the total population, $\mathrm{q}$-poor population.

Depth of poverty - estimates of the resources needed to bring the poor to the poverty line.

$$
P G=1 / n \sum_{i=1}^{q}\left(\frac{z-y i}{z}\right)
$$

where $y$-represents the income or expenses of the household, the established poverty line.

The severity of poverty-calculates inequalities between poor people and the distance between poor people and the established poverty line.

$$
P 2=1 / n \sum_{i=1}^{q}\left(\frac{z-y i}{z}\right)^{2}
$$

Starting from these methods combined with the statistical function of measuring poverty, its impact on economic growth and sustainability and poverty reduction can be determined.

In order to estimate the impact of primary indicators (including remittances) on economic growth and poverty reduction, the relationships can be analyzed:

$$
\begin{gathered}
\gamma_{i t}=\beta_{1} R_{i, t}+\beta_{2} X_{i, t}+\alpha_{i}+u_{i, t} \\
P_{i t}=\int\left(R_{i t}, Y_{i t}, I_{i t}, O_{i t}, \pi_{i t}\right)
\end{gathered}
$$

where the country represents and the time period, $Y_{i t}$ logarithm of GDP per capita; $R_{i t}$ represents the rate of remittances in GDP.

Matrix $X$ is a set of control variables that were found in the literature with an influence on economic growth and financial development: Inflation $\pi_{i t}$, measured as an annual percentage change in the consumer price index, opening $\left(O_{i t}\right)$ for international trade, differing as a ratio between the sum of exports and imports of goods in total production. Other flows in GDP, measured as the ratio of capital inflows to GDP (including aid and others);

$P_{i t}$ - poverty measured as a logarithm;

$I_{i t}$-investment measured as the natural logarithm of gross capital formation (percentage of GDP);

$$
P_{i t}=\int\left(R_{i t}, Y_{i t}, I_{i t}, O_{i t}, \pi_{i t}\right)
$$

The impact of remittances on poverty reduction can be estimated using expenditure as an indicator, by estimating the function:

$$
\log u_{i}=\alpha+\sum \beta_{i} X_{i j}+\varepsilon_{i}
$$

where:

$\varepsilon_{i}$ is the error term, which is assumed to be independent of a normal distribution; $u_{i}$ represents per capita expenditure, and $X_{i j}$ is a vector of explanatory variables, which con- 
tains information about remittances of the migrant population and economic shocks, which can be measured by food and non-food prices.

We propose to develop these models in the future, starting from the calculation of primary indicators and derivatives, and calculating models that highlight the wealth of the population and the impact of remittances on poverty, especially since at the national level alone we have over 4 million population in diaspora and around 5 million people at risk of poverty and who can be included through methods and models of social and financial inclusion and who directly contribute to the sustainability of the wealth of each individual and the nation as a whole.

\subsection{The Evolution of the Active Population in the Economy and the Labor Market}

Considering that the evolution of the primary indicators regarding the characterization of the financial status of the population in the period 2007-2019, especially for the active population, which is directly influenced by the quality of employment of fit and employed adults. Moreover, we appreciate that indicators such as the rate of financing the income of the population, the rate of financial saving of the population, net financial assets, and the net financing capacity of the economy are directly influenced by employment in economic sectors and the evolution of the labor market in Romania. Therefore, also according to the above-mentioned report, we present some relevant data regarding employment and the Romanian labor market.

Regarding employment, in the third quarter of 2020, according to data provided by the National Institute of Statistics (INS) [36], the employment rate of the population aged 20-64 was $71.2 \%, 1.2$ percentage points above the national target of $70 \%$ set in the context of the Europe 2020 Strategy. In the third quarter of 2020, Romania's active population was 9027 thousand people, of which 8555 thousand people were employed and 472 thousand people were unemployed.

At the same time, the Romanian labor market continues to face the constraint represented by demographic evolution. On 1 January 2017, Romania's resident population was $19,644.4$ thousand inhabitants, compared to $19,916.5$ thousand inhabitants in 2014. The negative values of the natural increase, combined with those of the international migration balance, made the country's resident population decrease, between 1 July 2014-1 January 2017, by 272.1 thousand people [37].

According to Eurostat, the highest employment rate in the EU-27 (for people aged 20 to 64 ) in 2005 was recorded in 2019, at 73.1\%. At the EU-27 level, the gender gap in employment narrowed compared to 2005, but the employment rate in 2019 was still 11.7 percentage points higher for men than for women.

According to the EU Report on Employment and Social Policies for the Euro 2020 [38], in the first half of 2020, the euro area labor market suffered a massive deterioration caused by the COVID-19 pandemic and measures taken to stop it. At the same time, the decline in employment, of about $4 \%$ in 2020 , hides a more substantial deterioration in the number of hours worked, as technically unemployed employees are in fact unemployed, being still considered employees only in terms of numbers. In order for a person to be considered unemployed, he or she must be available on the labor market, which was not possible everywhere during strict isolation measures, and many people with limited access to the labor market were also available.

\subsection{Challenges of the Labor Market}

Despite these developments, a number of challenges remain, in terms of economic and social inclusion, there are still large gaps between rural and urban areas, as well as at the regional level. Although most regions (8) in Romania have made progress in terms of key indicators for economic growth, they remain below the EU average, with the exception of the Bucharest-Ilfov region. However, the data published by Eurostat, the statistical office of the European Union, do not change last year's ranking, with Romania remaining, despite the economic growth of the last years, one of the poorest countries in the EU. 
Bulgaria (51\% of the EU average) and Croatia (63\% of the EU average) have a lower GDP/capita in PPS than Romania. Among the CEE countries, the Czech Republic is the most advanced, reaching 91\% of the EU average of GDP/capita in the PPS in 2028 on a par with Spain and more EU countries such as Portugal (77\%) or Greece (68\%). Poland is at $77 \%$ of the EU average GDP/capita in the PPS, Slovenia at $78 \%$, and Slovakia at $73 \%$ and Hungary at $71 \%$.

For income inequality (Figure 7), in 2017, Romania registered a value of the Gini indicator of 35.1, slightly higher than the previous year (34.7). Also, the S80/S20 report reflects the fact that in 2017 the first $20 \%$ of Romanians with the highest incomes earned seven times more than the $20 \%$ of those with the lowest incomes, the report experiencing a slight improvement compared to the previous year.

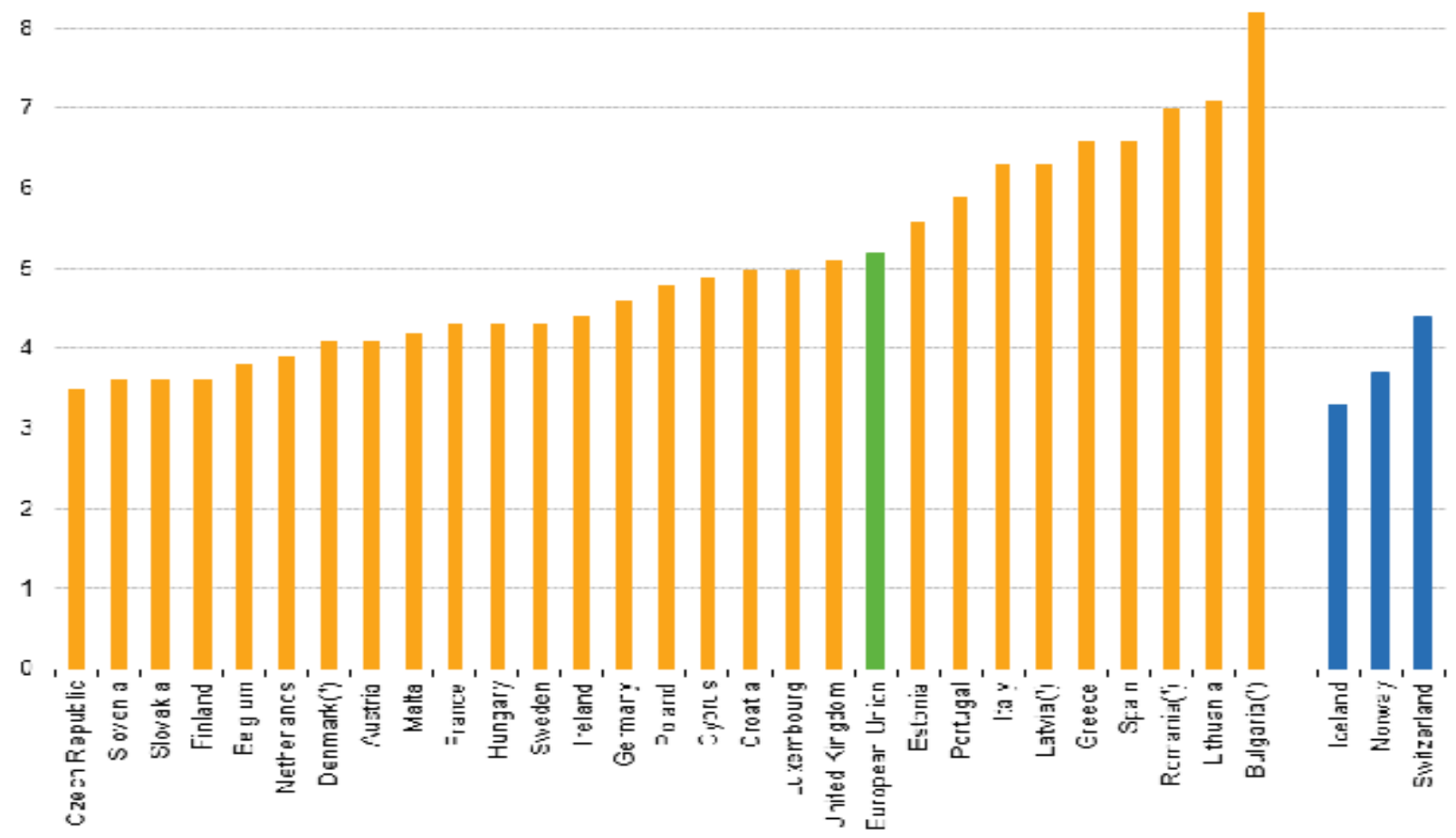

Figure 7. Inequality of total income distribution. Source: Eurostat, 2020 [19].

For the labor market participation rates, which despite the labor shortage, remain low in the case of categories of people considered vulnerable in relation to the labor market. The rate of unemployed young people aged 15-24, who do not attain any form of education or training (NEET rate), although declining since 2015, continues to be relatively high (compared to the EU average), standing at 15, 2 in 2017, respectively at the value of 14.8 in the third quarter of 2018, and in 2019, the rate reached the value of $16.816 .8 \%$ [39].

Structural changes induced by rapid technological developments such as digitization, automation, robotics, or artificial intelligence, as well as the growing demand for skills are considerable challenges for the training system and for adults in a labor market that evolving at a rapid pace.

In order to benefit from the proposed Recovery and Resilience Mechanism, Member States need to draw up recovery and resilience plans and attach them to their national reform programs, taking into account the results of the European Semester, as well as national energy and climate plans. and plans for a fair transition to reporting on progress in implementing these plans in the context of the European Semester. Member States must draw up specific plans for making progress in the social field, setting out clear objectives and indicating the exact areas to be covered by social investment and how the principles of the Social Rights Pillar will be applied following the adoption of the plan action plan for the construction of the pillar announced by the President of the European Commis- 
sion. Socially sustainable reforms are those based on solidarity, integration, social justice, equitable distribution of wealth, gender equality, high-quality public education system for all, jobs for quality, and sustainable growth - a model that ensures equality and social protection, empowers vulnerable groups, promotes citizen participation and involvement and improves the standard of living of all citizens; whereas strengthened social protection systems are essential to combat poverty and inequality, as well as to support sustainable and inclusive growth.

The crisis will significantly deteriorate social conditions, especially affecting lowincome women, households, and families, the elderly, minorities, and other vulnerable groups, leading to rising inequalities, precariousness, poverty, unemployment, and social discrepancies while undermining standards the social and employment services in Europe. Among other categories, young people, workers with precarious working conditions, atypical or temporary contracts, low-skilled people, workers in involuntary employment and part-time employment, as well as workers in platforms and migrant workers are at greatest risk of losing their jobs and being affected by poverty. Many workers with key occupations for the front-line response to the COVID-19 pandemic belong to these vulnerable categories.

Professional activities undergo profound changes determined by technological innovations, digitalization, demographic changes, climate change, and globalization; whereas, moreover. The current crisis has had a huge impact on our work habits; whereas the use and promotion of digital technologies in an inclusive way can bring long-term economic and social benefits, improve competitiveness and create professional opportunities but can also lead to difficulties such as social isolation, digital exclusion, deepening inequalities, data protection, deterioration of workers' health and working conditions, as well as deterioration of workers' rights. Investing in digital skills, digital skills, and formal adult vocational training in the digital field improves the employability of workers, the evolution of wages, and the competitiveness of businesses. The global challenges mentioned above call for a just transition so that no one is left behind.

The European Union recovery tool entitled "Next Generation EU" calls for a balanced approach to the green and digital transition, on the one hand, and to social, education, and health infrastructure, on the other. It insists that the recovery plan be fully in line with the European Pillar of Social Rights and contribute to the achievement of the UN SDGs and the European Green Pact, calls on the Member States to make use of the general derogation clause and to invest in people and social protection systems and to support viable businesses in difficulty in order to protect jobs and wages. It also calls for the development of specific social progress plans to make social protection systems more effective, equitable, and robust. Lastly, it calls for an ambitious multiannual financial framework (MFF), strengthened by new own resources and rejects any reduction in funding for cohesion-focused programs, such as the ESF+.

\section{Conclusions}

The interpretation of the evolution of the indicators took into account the correlated and corresponding evolutions of the absolute values of the primary indicators, presenting the evolutions, on the same graph, of the relevant relative indicators, but also of the determining primary indicators. Moreover, the primary data identified were based on the databases of the National Bank of Romania (from the National Financial Accounts 2007-2019 and the monthly bulletins from 2007 to 2020) and the National Institute of Statistics (Statistical Yearbook of Romania, editions 2007-2019, Monthly statistical bulletin from December 2007-2020).

The analyses so far of the financial indicators relevant to the household sector, allow us to draw some general conclusions regarding the characteristics highlighted by the population, from a financial point of view, in the analyzed period, namely:

Fluctuating evolutions of relevant financial indicators, often contrary to the financial dynamics of a market economy, mainly due to two factors: the strong intrusion of the 
political factor, accompanied by insecure and uncompetitive governance; the distortions that characterized the evolution of the financial system, of the banking system in full financial crisis, after 2009, and until 2018. For example, the evolution of the indicator Income Banking Rate of the degree of employment of the population in activities on the banking and financial markets allows knowing the state and evolution of the financial behavior of the population, for the forecast and design of this indicator, as well as for the elaboration of monetary policies.

The reduced financial potential of the population, compared to that of the countries recently entered the EU but also compared to the needs of the development of the saving-investment cycle, primordial to the beneficial evolution of the economy. In this sense, the assertion of the population as the priority internal financier of the economy, often unique, which highlights the shortage of investment opportunities specific to households, in an economy with financial resources that are rather unviable, is authentic.

Relevant indicators for assessing the financial status of the population are directly influenced by the evolution of national and European representative indicators, such as the evolution of economic growth, the evolution of the active population in the economy and labor market, the evolution of public, and the evolution of demographic change at the national and European level.

The evolution of the primary indicators regarding the characterization of the financial status of the population in the period 2007-2019, especially for the active population, is directly influenced by the quality of employment of fit and employed adults. Furthermore, we appreciate that indicators such as the rate of financing the income of the population, the rate of financial saving of the population, net financial assets, and the net financing capacity of the economy are directly influenced by employment in economic sectors and the evolution of the labor market, both at the national and European level.

Decorations and dynamic deviations between the relevant financial indicators, derived from absolute financial indicators, highlight the still turbulent state of financial flows and circuits in the economy.

At the level of 2019, in the EU, we notice that Romania is, from the perspective of both components (assets and liabilities), at the "tail" of the ranking. Financial assets relative to GDP increased in the EU, but in Romania, households have the lowest value of financial assets relative to GDP, only a third of the EU average in 2019.

In terms of household financial assets, Romania has a share of $71.6 \%$ of the GDP, the states that outperform it, with significant distance values, being Latvia (91.1\%), Slovakia (95.2\%), and Poland (98.5\%). The countries in the first few places are Denmark ( $348 \%$ of GDP, about five times more than the level in Romania), the Netherlands, and Sweden (shares exceeding $300 \%$ of GDP).

Regarding the financial debts of Romania (\% of GDP), in 2019 they totaled $20.7 \%$ of GDP, countries in the immediate vicinity being Hungary (22.1\% of GDP), Latvia (22.5\%), or Bulgaria $(29 \%)$. Also, countries with a very high level of debt are Denmark $(116.5 \%$, 5.63 times more compared to Romania), Cyprus, or the Netherlands (weights exceeding $100 \%$ of GDP).

In the next period, the economic effects of the COVID-19 pandemic are expected to affect the balance sheet position of the population sector, both in terms of net wealth, due to deteriorating conditions in the real estate and capital markets, and from the perspective of revenue reduction. Our research team aims to continue research and develop the analysis of primary and derivative indicators, developing supporting economic models for economic sustainability in the context of pandemic challenges. As it results from the presentation of the research results at the end of 2019, the wealth of the population was for the first time above the value recorded at the end of 2008, but non-financial assets had a share of $81 \%$ of the total, down 10 percentage points from recorded in 2008. Diversification of the population's wealth into other asset classes reduces the impact of negative shocks on the real estate market. The potential difficulties of the population can also spread to the 
banking sector, with ongoing loans in this case accounting for about $31 \%$ of total exposures to the population sector.

These developments demonstrate the importance of maintaining a prudent level of indebtedness during periods of economic expansion, in order to allow borrowers to absorb potential negative developments as the economy declines [40]. The decrease in indebtedness at the debtor level in the last period indicates that the NBR measure to avoid over-indebtedness of individuals was beneficial and achieved its objectives of sustainable growth of financial intermediation. Given that this macroprudential measure was implemented long before the COVID-19 pandemic broke out, the contribution of the high indebtedness of the population as an amplifying factor in increasing the probability of default is very limited [41]. It should also be mentioned that calculating and analyzing these primary indicators and derivatives at the level of the population from a financial point of view can support through concrete measures the evaluation of access to financing, provided that the degree of financial intermediation in Romania remains the lowest. From the European perspective, the research work is oriented towards the applicative aspect, building a tool for the banking financial institutions that helps with making the decision to finance the population and the decision to finance by government credit the national institutions.

The current context demonstrates the importance of a proactive macro-prudential policy that builds early, in times of economic expansion, adequate capital and liquidity reserves to be used when adverse developments occur [40]. From this point of view, the native banking sector was prepared to manage medium-high intensity effects generated by the COVID-19 pandemic.

Finally, as many studies suggested [6,41,42], a frugal economy can be considered an important strategy in crisis response thus we suggest that the economy of Romania should focus on frugal innovation. A frugal economy system endeavors to provide welfare focusing on more economic, social, and ecological values, aiming to maximize the efficient utilization of resources and finances in the country from the perspective of all stakeholders in the economy. Regarding the limitations of the research, we can appreciate that the relevant statistical data for 2020 are not yet available. Moreover, we intend to continue research with the same research topic. We recommend deepening the existing indicators at the national level so that the orientation of the action directions at the national level is in the direction of sustainable development at the national level.

Author Contributions: Conceptualization, O.M. and E.H.; methodology, O.M. and E.H.; software, O.M.; validation, O.M., E.H. and A.K.; formal analysis, O.M.; investigation, O.M.; resources, O.M.; data curation, O.M.; writing-original draft preparation, O.M.; writing-review and editing, E.H. and A.K.; project administration, O.M.; funding acquisition, O.M. Please turn to the CRediT taxonomy for the term explanation. Authorship must be limited to those who have contributed substantially to the work reported. All authors have read and agreed to the published version of the manuscript.

Funding: This research received no external funding.

Institutional Review Board Statement: Not applicable.

Informed Consent Statement: Not applicable.

Data Availability Statement: Not applicable.

Acknowledgments: We appreciate four anonymous reviewers for their insightful suggestions and constructive comments. We are grateful to the editors for their patient work on our manuscript and many thanks for all your support.

Conflicts of Interest: The authors declare no conflict of interest.

\section{References}

1. MITSloan. Available online: https://sloanreview.mit.edu/article/the-rising-frugal-economy/ (accessed on 29 April 2021). 
2. Bhatti, Y.; Andrea, T.; Matthew, H.; Hester, W.; Erin, E.; Matt, P.; Hannah, P.; Alexander, W.C.; Parston, G.; Ara, W.D.; et al. Global lessons in Frugal innovation to improve health care delivery in the United States. Health Aff. 2017, 36, 1912-1919. [CrossRef] [PubMed]

3. Kahle, H.N.; Anna, D.; Ernst, P.; Prabhu, J. The democratizing effects of frugal innovation: Implications for inclusive growth and state-building. J. Indian Bus. Res. 2013, 5, 220-234. [CrossRef]

4. Sarkar, S. Breaking the chain: Governmental frugal innovation in Kerala to combat the COVID-19 pandemic. Gov. Inf. Q. 2021, 38, 101549. [CrossRef] [PubMed]

5. Mannelli, C. Whose life to save? Scarce resources allocation in the COVID-19 outbreak. J. Med. Ethics 2020, 46, 364-366. [CrossRef] [PubMed]

6. Corsini, L.; Dammicco, V.; Moultrie, J. Frugal innovation in a crisis: The digital fabrication maker response to COVID-19. RED Manag. 2021, 51, 195-210.

7. Radjou, N.; Prabhu, J.; Ahuja, S. Jugaad Innovation: Think Frugal, Be Flexible, Generate Breakthrough Growth; John Wiley \& Sons: Hoboken, NJ, USA, 2012.

8. Hysa, E.; Kruja, A.; Rehman, N.U.; Laurenti, R. Circular economy innovation and environmental sustainability impact on economic growth: An integrated model for sustainable development. Sustainability 2020, 12, 4831. [CrossRef]

9. Kaur, G.; Kaur, C. COVID-19 and the Rise of the New Experience Economy. FIIB Bus. Rev. 2020, 9, 239-248. [CrossRef]

10. Mani, S. India's Role in Frugal Innovations in Health-Related Technologies to Deal with COVID-19 Opportunities and Constraints; Centre for Development Studies: Thiruvananthapuram, India, 2020.

11. Hickey, R.; Lozej, M.; Smyth, D. Financing government investment and its implications for public capital: A small open economy perspective. Econ. Model. 2020, 93, 620-641. [CrossRef]

12. Slavescu, V. (Ed.) Romania's Financial Situation, 2019, 2020; Center for Financial and Monetary Research (CCFM). Available online: http:/ / www.icfm.ro/ (accessed on 30 April 2021).

13. National Bank of Romania. Database from the National Financial Accounts 2007-2019 and the Monthly Bulletins from 2007-2020; National Bank of Romania: Bucharest, Romania, 2020.

14. National Institute of Statistics. Statistical Yearbook of Romania, Editions 2007-2020, Monthly Statistical Bulletin from December 2007-2019; National Bank of Romania: Bucharest, Romania, 2019.

15. Jagrič, T.; Brown, C.; Boyce, T.; Jagrič, V. The impact of the health-care sector on national economies in selected European countries. Health Policy 2021, 125, 90-97. [CrossRef]

16. d'Albis, H.; Boubtane, E.; Coulibaly, D. Immigration and public finances in OECD countries. J. Econ. Dyn. Control 2019, 99, 116-151. [CrossRef]

17. Peña, W. Population Aging and Public Finances: Evidence from El Salvador. J. Econ. Ageing 2020, 17, 100260. [CrossRef]

18. Ioan, B.; Malar Kumaran, R.; Larissa, B.; Anca, N.; Lucian, G.; Gheorghe, F.; Horia, T.; Mircea-Iosif, R. A Panel Data Analysis on Sustainable Economic Growth in India, Brazil, and Romania. J. Risk Financ. Manag. 2020, 13, 170. [CrossRef]

19. Ioan, B.; Malar Kumaran, R.; Larissa, B.; Anca, N.; Lucian, G.; Gheorghe, F.; Horia, T.; Mircea-Iosif, R. Adjusted Net Savings of CEE and Baltic Nations in the Context of Sustainable Economic Growth: A Panel Data Analysis. J. Risk Financ. Manag. 2020, 13, 170. [CrossRef]

20. Anghelache, C.; Anghel, M.G.; Solomon, A.G. The Effect of Migration on Labor Resources. Int. J. Acad. Res. Account. Financ. Manag. Sci. 2017, 7, 6-13. [CrossRef]

21. Anghelache, C.; Anghel, M.G.; Panait, M. The Main Developments and Perspectives of the European Union. Rom. Stat. Rev. 2017, 2, 57-79.

22. Anghelache, C.; Georgiana, N.I.T.A.; Badiu, A. Migration and Remittances-statistical-econometric models used in the analysis of remittances in economic development. Rom. Stat. Rev. Suppl. 2017, 65, 134-143.

23. Anghelache, C.; Niță, O.G.; Badiu, A. Migrants remittances-An important and stable source of external funds, in the economic development of a country. Rom. Stat. Rev. Suppl. 2016, 64, 86-92.

24. Anghelache, C.; Sfetcu, M.; Popovici, M.; Dinca, Z. General aspects regarding the concept of economic growth. Rom. Stat. Rev. Suppl. 2016, 10, 67-70.

25. Farole, T.; Rodríguez-Pose, A.; Storper, M. Cohesion Policy in the European Union: Growth, Geography, Institutions. J. Common Mark. Stud. 2011, 49, 1089-1111. [CrossRef]

26. Fleurbaey, M. Beyond GDP: The Quest for a Measure of Social Welfare. J. Econ. Lit. 2009, 47, 1029-1075. [CrossRef]

27. Voigt, P.; Moncada-Paternò-Castello, P. Can Fast Growing R\&D- of Intensive Smes Affect the Economic Structure the EU Economy? A Projection to the Year 2020. Eurasian Bus. Rev. 2012, 2, 96-128.

28. Aisen, A.; Veiga, F.J. How does political instability affect economic growth? Eur. J. Political Econ. 2013, 29, 151-167. [CrossRef]

29. Anghelache, C. Economic Situation; Economic Publishing House: Bucharest, Romania, 2016.

30. Anghel, M.G.; Anghelache, C.; Niță, G. Analysis of the influence international trade on economic growth in the European Union. Rom. Stat. Rev. Suppl. 2017, 65, 170-184.

31. Manta, O.; Gouliamos, K.; Kong, J.; Li, Z.; Ha, N.M.; Mohanty, R.P.; Yang, H.; Pu, R.; Yue, X.-G. The Architecture of Financial Networks and Models of Financial Instruments According to the "Just Transition Mechanism" at the European Level. J. Risk Financ. Manag. 2020, 13, 235. [CrossRef]

32. Anghelache, C.; Partachi, I.; Anghel, M.G. Forecasting economic growth. Econ. Sci. Didact. J. XXIV 2017, 2, 147-152. 
33. Ministry of Public Finance. Report on the Final Budget Execution for 2019. Available online: https://ec.europa.eu/info/sites/ default/ files/2020-european-semester-convergence-programme-romania_en.pdf (accessed on 30 April 2021).

34. Regulation of the National Bank of Romania no. 6/2018. Available online: https://www.reff-associates.ro/re/en/pages/newsand-resources/legal-alerts/lending-conditions-the-amendments-made-by-the-national-bank-of-romania-through-regulation. html (accessed on 30 April 2021).

35. Regulation of the National Bank of Romania. Available online: https://www.esrb.europa.eu/mppa/cbmd/shared/pdf/ Romania/2013-12-09_Regulation_17-2012.pdf?bf3a1c339ea76c300fc1c2ef2fd03acf (accessed on 30 April 2021).

36. National Institute of Statistics. Available online: https://insse.ro/cms/en/content/statistical-publications-archive-2007--2019 (accessed on 30 April 2021).

37. EU Report on Employment and Social Policies for the Euro 2020. Available online: https:/ / www.europarl.europa.eu/doceo/ document/A-9-2020-0183_EN.html (accessed on 30 April 2021).

38. Eurostat 2020. Available online: https: / / ec.europa.eu/ eurostat (accessed on 30 April 2021).

39. European Commission. Available online: https://ec.europa.eu/eurostat/statistics-explained/index.php/Statistics_on_young_ people_neither_in_employment_nor_in_education_or_training (accessed on 30 April 2021).

40. National Bank of Romania. Financial Stability Report; National Bank of Romania: Bucharest, Romania, 2020.

41. Vesci, M.; Feola, R.; Parente, R.; Radjou, N. How to save the world during a pandemic event. A case study of frugal innovation. RED Manag. 2021. [CrossRef]

42. Furini, M.; Mirri, S.; Montangero, M.; Prandi, C. Can IoT Wearable Devices Feed Frugal Innovation? In Proceedings of the 1st Workshop on Experiences with the Design and Implementation of Frugal Smart Objects, New York, NY, USA, 21 September 2020; pp. 1-6. 